\title{
Japan Sea, opening history and mechanism: A synthesis
}

\author{
Laurent Jolivet \\ Département de Géologie, Ecole Normale Supérieure, Paris, France \\ Kensaku Tamaki \\ Ocean Research Institute, University of Tokyo, Tokyo, Japan \\ Marc Fournier \\ Département de Géologie, Ecole Normale Supérieure, Paris, France
}

\begin{abstract}
The respective tectonic effects of back arc spreading and continental collision in Asia are considered either as two independent processes or as closely interrelated. Extrusion tectonics assumes that the opening of the South China Sea and the left-lateral motion along the Red River fault are geometrically linked in a pull-apart manner. This model is not accepted by several workers because the structural link between the two processes is not clearly demonstrated. In the case of the Japan Sea, we can show without ambiguity that back arc opening was controlled by large intracontinental strike-slip faults which can be easily understood as effects of the India-Asia collision far from the indenter. The Japan Sea opened in the early Miocene in a broad pull-apart zone between two major dextral strike-slip shear zones. The first one extends from north Sakhalin to central Japan along $2000 \mathrm{~km}$, it has accommodated about $400 \mathrm{~km}$ of finite displacement.

Deformation along it varies from dextral transpression in the north to dextral transtension in the south. The second is between Korea and SW Japan and has accommodated a smaller displacement of about $200 \mathrm{~km}$. The extensional domain in between lies in the back arc region of Japan. Distributed stretching of the arc crust resulted in the formation of most of the Japan Sea, while localized oceanic spreading at the southern termination of the eastern transpressional shear zone shaped the Japan Basin. The first oceanic crust was formed in a small triangle based on the eastern shear zone, and spreading propagated westward inside the pull-apart region. Timing of oceanic crust formation, of formation of the dextral shear zones and of block rotation in between, as well as the internal structure of the basins and the geometry of deformation along the master shear zones are used to reconstruct the opening history. This evolution is discussed by comparison to other manifestations of the arc and back arc activity, such as the history of sedimentation and volcanism. The paper then suggests that the collision of India can have tectonic consequences as far north as Japan and Sakhalin and describes the geometrical relation of back arc opening there and diffuse extrusion.
\end{abstract}

\section{Introduction}

The deformation of Asia (Figures 1 and 2) is viewed commonly as if the region north of the indenter (Tibetan plateau, Tien Shan) and immediately east of it (Indochina) is deformed as a response to the Himalayan collision only and the back-arc regions along the Sunda and Pacific trenches are deforming as an effect of subduction only, without any link between both. Moreover, most papers dealing with the Cenozoic deformation of the Asian continent describe it in such a way that the influence of the eastern and southeastern plate boundaries is ignored, although it is obvious that large extensional and strike-slip deformation is concentrated in the back arc regions of the Sunda and Pacific subduction trenches. Finite deformation

Copyright 1994 by the American Geophysical Union.

Paper number 93JB03463.

0148-0227/94/93JB-03463\$05.00 is discussed generally in terms of extrusion versus crustal thickening as a result of the indentation of Asia by India (see, for instance, a recent discussion by Dewey et al. [1989] or Le Pichon et al. [1992]). The opening of the South China Sea is, for instance, seen by Tapponnier et al. [1982] and Peltzer and Tapponnier [1988] as the result of extrusion of Indochina alone. The merely passive role of the subduction zone played in these schemes is very unlikely, however, given that large back arc basins opened along the eastern border of the Philippine Sea plate (Shikoku-Parece Vela Basin) as a response to the particular stress conditions created in the upper plate by the subduction of the Pacific plate. Far from the indenter, the most obvious deformation features related to collision are localized strike-slip shear zones such as the Red River fault or the Altyn Tagh fault. Further away from it, marginal basins have opened during the collision process, and one can consider collision as a possible cause for opening [Tapponnier et al., 1982; Kimura and Tamaki, 1986; Jolivet et al., 1990]. This paper deals with the opening mechanism of marginal basins settled onto the 


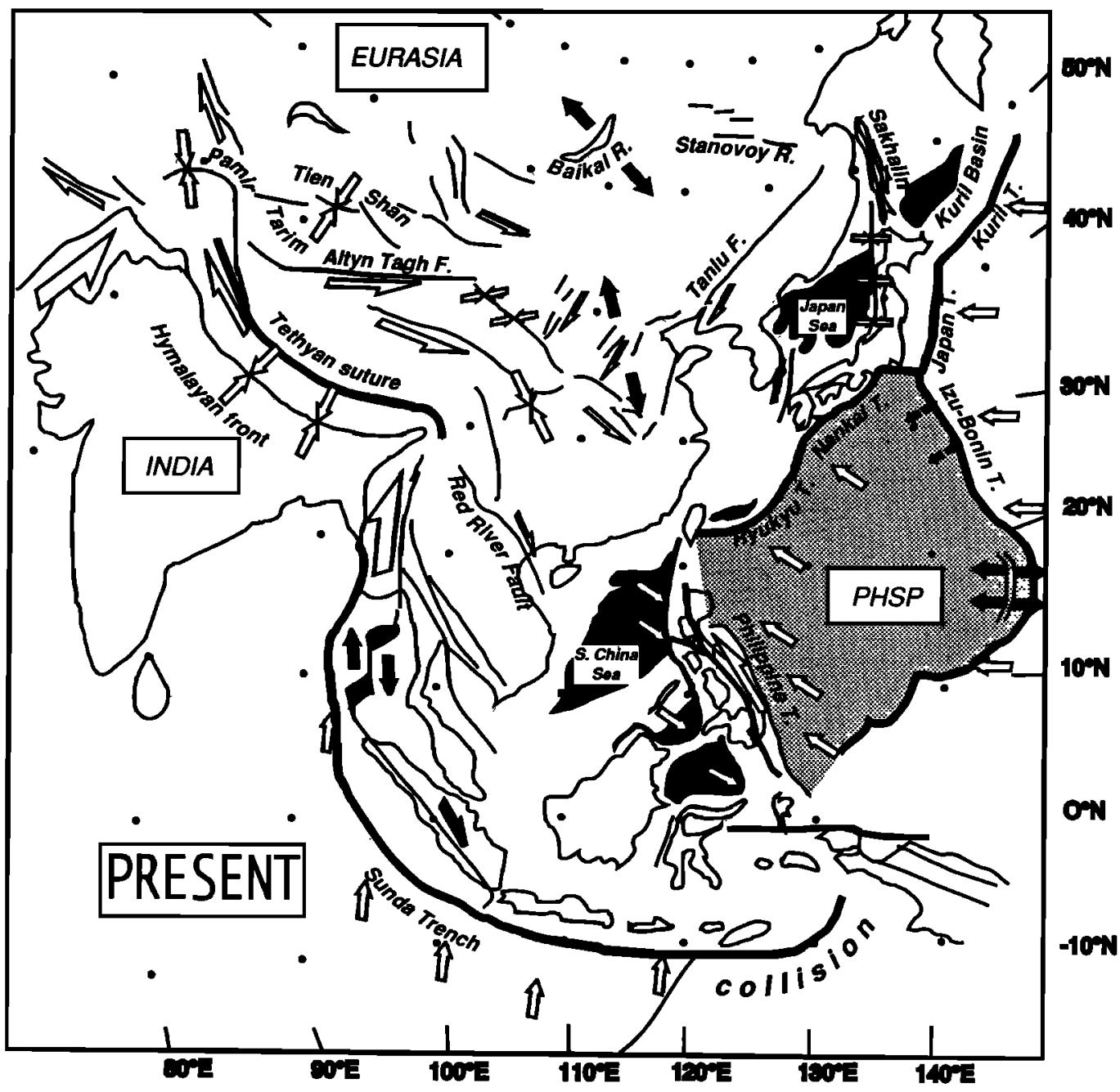

Figure 1. General geodynamic framework of Asia, Southeast Asia, and the northwest Pacific. Fault pattern inside Asia after Tapponnier et al. [1982].Double open arrows represent the direction of relative convergence across intracontinental thrust zones, open semi-arrows represent the sense of relative motion along major strike-slip faults, open single arrows represent relative direction of motion of the subducting plate in subduction zones, and solid divergent arrows represent direction of relative divergence across major zones of extension.

margin of the deforming Eurasia and shows how back arc opening and intracontinental strike-slip faults cooperate to shape those basins on the example of the Japan Sea.

Most of the northwest Pacific large back arc basins opened between the late Oligocene to middle Miocene [Taylor and Karner, 1983; Mrozowski and Hayes, 1979; Taylor and Hayes, 1983; Tamaki, 1986; Briais, 1989; Chamot-Rooke et al., 1987; Taylor et al., 1990; Rangin et al., 1990a, b; Tamaki and Honza, 1991]. Most are now in a closing stage [Tamaki and Honza, 1984; Rangin and Silver, 1991], active back arc spreading and rifting being active only along the eastern margin of the Philippine Sea plate in the Mariana trough [Karig et al., 1978; Stern et al., 1984] and Bonin rift [Taylor, 1992], and in the Okinawa trough [Wageman et al., 1970; Kimura, 1985; Letouzey and Kimura, 1985; Sibuet et al., 1987]. That the largest basins opened at almost the same time from the Sulu Sea to the Kuril basin on the Eurasian margin, and the Shikoku-Parece Vela basin on the eastern margin of the Philippine Sea plate makes it unlikely that the opening is due only to collision because there is a priori no link between the internal deformation of the Philippine Sea plate and the India-Eurasia interactions. Pacific subduction obviously played a large role in the opening, as recognized earlier by most authors working on marginal basins [Karig, 1971; Uyeda and Kanamori, 1979; Uyeda, 1986; Viallon et al., 1986; Uyeda and McCabe, 1983; Tamaki and Honza, 1991; Honza, 1991]. Analog experiments performed by Shemenda [1993] show that trench roll back and back arc opening during fast convergence are physically feasible. In some conditions, tensional stresses can be applied to the upper plate and lead to the opening of oceanic basins above a convergent zone. The geometry of the East Asian marginal basins is, however, controlled by large strike-slip faults, which can hardly be related to the subduction process only. The Red River fault has, for instance, accommodated some $500 \mathrm{~km}$ of left-lateral displacement during the South China Sea opening, 


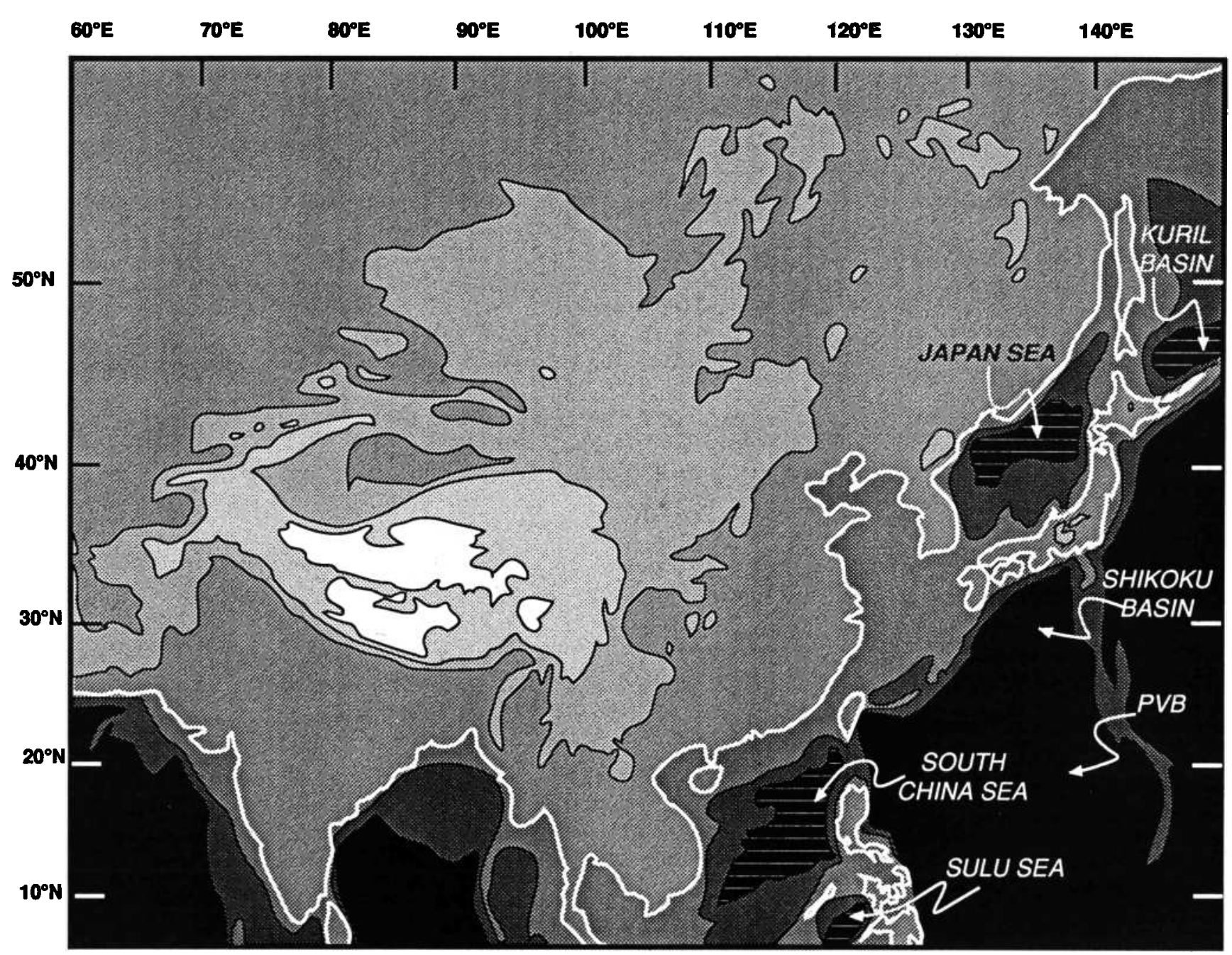

Figure 2. General bathymetry and topography of Asia and west Pacific. Contours: 5000, 3000, 1000, 0, -1000 , and -3000 are represented. Regions deeper than 3000 meters (oceanic crust in general) in marginal seas are ruled.

according to Tapponnier et al. $[1982,1986,1990]$ or Peltzer and Tapponnier [1988]. Dextral motion is known also along the margins of the Japan Sea and extends 2000 $\mathrm{km}$ far from the subduction zone along northeast Japan and Sakhalin [Lallemand and Jolivet, 1985; Jolivet and Miyashita, 1985; Jolivet and Huchon, 1989; Jolivet et al., 1991, 1992; Fournier et al., 1994]. Total dextral offset was recently quantified to a minimum $400 \mathrm{~km}$ [Jolivet and Tamaki, 1992]. Cenozoic N-S dextral strike-slip motion is recorded also in the region of the North China basin [Chen and Nabelek, 1989].

We discuss this problem based on the example of the Japan Sea, which now provides a well-controlled history of rifting and spreading, in terms of geometry and timing. Geophysical and geological data that were used until recently to constrain the tectonic history of the Japan Sea gave rise to contradictory models, mostly because hard data concerning the age of rifting and spreading were lacking. It is only very recently that Ocean Drilling Project (ODP) legs 127 and 128 brought inescapable evidence that it opened during a 10 to 15 m.y. time span from the end of the Oligocene to the middle Miocene. These results confirmed some of the earlier conclusions based on heat flow and basement depth [Tamaki, 1988] and the tectonic history of the margins [Iijima and Tada, 1990, and references therein]. It instead contradicts the classical consideration that the Japan Sea opened by fast rigid rotations in a bar-door fashion, as deduced from paleomagnetic data (Otofuji and Matsuda [1983], and subsequent papers). Subsidence history of several sections inside the basin and along the margins [Ingle, 1992] is also consistent with the pull-apart model that we proposed earlier [Lallemand and Jolivet, 1985; Jolivet et al., 1991].

\section{Present Tectonic Environment of the Japan Sea}

Opening in the Japan Sea stopped sometime in the middle Miocene, and a new compressional tectonic context was set about 10 m.y. ago and ultimately led to the formation of an incipient subduction zone inside the basin in the early Quaternary.

\section{Compression and Incipient Closure}

The present-day NE Japan arc is everywhere under E-W compression (Figure 3), approximately parallel to the direction of relative convergence between the Eurasia and 


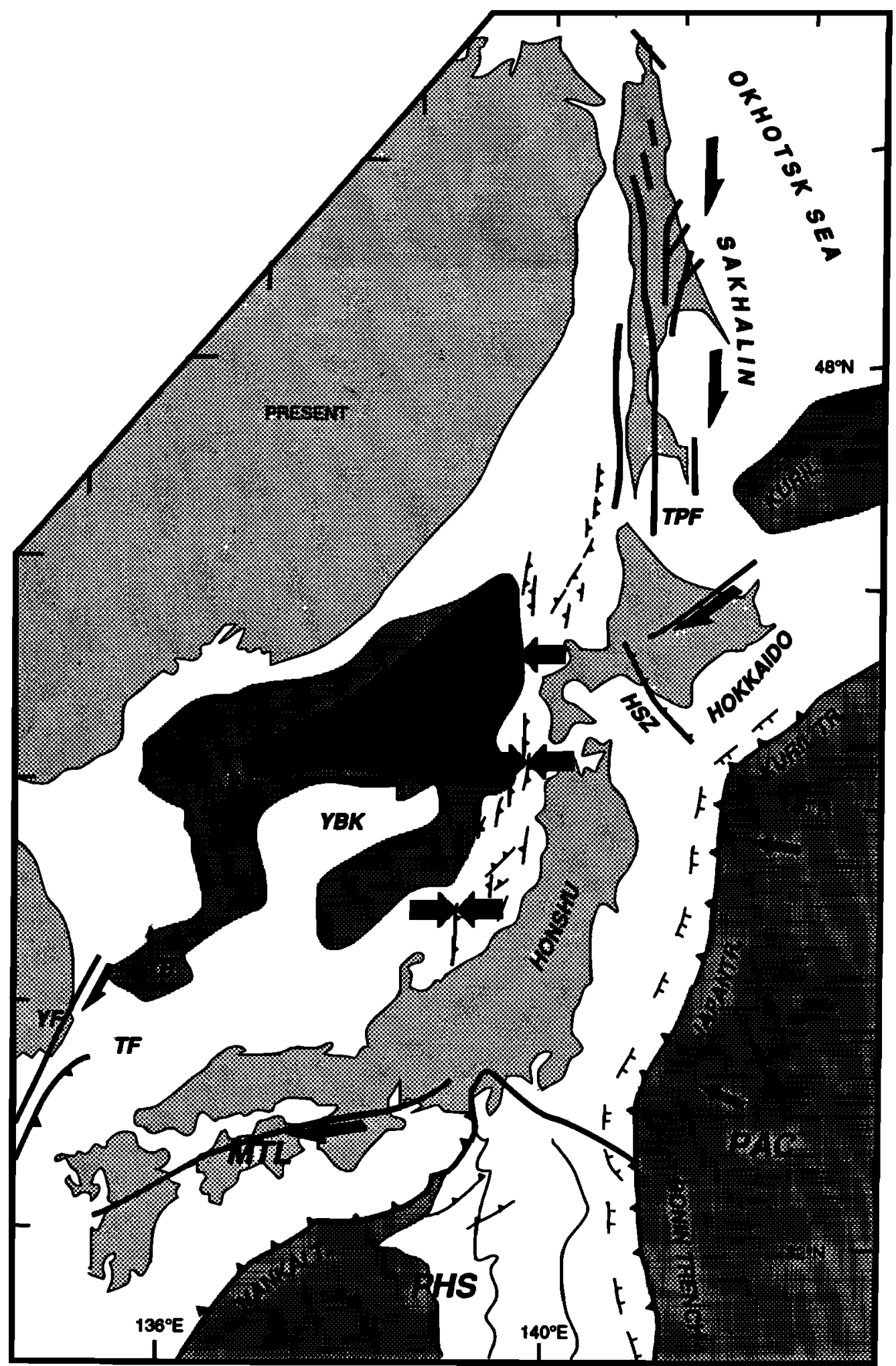

Figure 3. Present-day tectonic context in the Japan Sea region showing the direction of relative convergence or strike-slip motion along the major zones of deformation. TPF, Tym-Poronaysk fault; HSZ, Hidaka shear zone; YBK, Yamato bank; TB, Tsushima basin; TF, Tsushima fault; YF, Yangsan fault; PHS, Philippine Sea plate.

Pacific plates [Fukao and Furumoto, 1975; Nakamura, 1983; Nakamura and Uyeda, 1980; Seno, 1985; De Mets, 1992]. The arc is currently undergoing uplift, which started some 5 to 6 m.y. ago [Sugi et al., 1983]. Recent uplift is recorded also on the inner wall of the Japan trench in the subsidence curves of several ODP and Deep Sea Drilling Project (DSDP) drilling sites [Von Huene and Lallemand, 1990]. Active crustal deformation is localized along the subduction contact as well as a N-S trending narrow zone along the eastern margin of the Japan Sea 
[Fukao and Furumoto, 1975]. Large-magnitude compressional earthquakes frequently occur there, in a zone where numerous active reverse faults are recognized [Tamaki and Honza, 1984]. Nakamura [1983] suggested that this active zone is the southernmost extension of the North America-Eurasia plate boundary which extends from eastern Siberia to Sakhalin and Japan [Chapman and Solomon, 1976]. En échelon troughs were further interpreted by Nakamura [1983] as a nascent subduction zone. This hypothesis was tested kinematically by several authors, first Seno [1977], and then De Mets [1992] with the NUVEL-1 data set, and it seems to be a viable kinematic solution.

Further north active seismic deformation is recorded in Sakhalin. It has been interpreted as the result of either pure E-W compression [Chapman and Solomon, 1976] or dextral transpression [Savostin et al., 1983; Jolivet et al., 1992; Fournier et al., 1994]. The coexistence of compressional and strike-slip events, the latter being localized along major reactivated Miocene strike-slip faults such as the Tym-Poronaysk fault (see Figure 6), and the observation of recent dextral offset in northernmost Sakhalin by Rozhdestvenskyi [1982] led us to conclude that dextral transpression occurs. This deformation is part of a continuous tectonic development which started in the Oligocene (see below).

\section{Collision of the Izu-Bonin Arc With Central Japan}

The present-day plate configuration puts the PacificPhilippine Sea-Eurasia triple junction in the southeastern corner of the Japan arc and the Philippine Sea Plate/Eurasia (PHSP/EUR) rotation pole is located close to the collision zone [Seno, 1977; Ranken et al., 1984; Huchon, 1985]. This situation is fairly recent, and most kinematic reconstructions show the triple junction moving along the eastern margin of Eurasia from south to north and reaching its present position in the middle Miocene [Jolivet et al., 1989; Haston and Fuller, 1991; Hall et al., 1993]. In this region, two buoyant features, the Japan and Izu-Bonin arcs meet and collide [Matsuda, 1978; Niitsuma and Akiba, 1985]. The northernmost tip of the Bonin arc (Izu peninsula) is being accreted to central Japan along several thrust contacts. As described by Taira et al. [1989], older collisions occurred since the middle Miocene, in the form of a sequential accretion of pieces of the Bonin arc to central Japan. Compression is recorded in the area north of the collision zone with a fan-shaped pattern of stress, which merges to the north with the E-W compression of NE Japan [Huchon, 1985]. Large strikeslip faults such as the Itoigawa-Shizuoka tectonic line are reactivated as sinistral transpressional wrench, and the thick late Cenozoic sediments of the Fossa Magna suffer shortening.

\section{Slow Dextral Motion Along the Median Tectonic Line}

West of the collision zone, subduction of the Philippine Sea plate occurs at a slow rate of 2-4 cm/year [Seno, 1977; Ranken et al., 1984]. A slight obliquity of the relative motion vector induces a partitioning of strain between pure compression in the Nankai trench and a slow dextral motion along the Median tectonic line [OKada, 1980].

\section{Dextral Transpression in South Korea}

Crustal seismic activity is recorded also in the Tsushima Strait, and recent activity is observed along the Yangsan fault in South Korea [Jun, 1990]. Strike-slip focal mechanisms with a notable compressional component have been computed by Jun [1990], who concludes that a NE-SW trending zone of dextral transpression exists between the Korean peninsula and Japan arc.

\section{Crustal Structure and Age}

Proper oceanic crust is found only in a restricted domain of the Japan basin, which has a triangular shape with its base along the eastern margin of the back arc basin [Tamaki et al., 1992]. Its seismic velocity structure and the recognition of magnetic anomalies ascertain its oceanic nature [Tamaki and Kobayashi, 1988]. It roughly corresponds to the area deeper than $3000 \mathrm{~m}$. Between 3000 and $2000 \mathrm{~m}$, stretched arc crust is distributed in the Yamato and Tsushima basins as well as in the western part of the Japan basin [Tamaki, 1988; Tokuyama et al., 1987]. The velocity structure of the Yamato basin shows the same vertical superposition as in the nearby Japan arc except for its thickness and the absence of the $6.0 \mathrm{~km} / \mathrm{s}$ layer. It is much too thick for a normal oceanic crust and has been interpreted as highly stretched arc crust intruded by mafic dykes and sills [Tokuyama et al., 1987]. In the middle of the basin, the Yamato bank again shows the same structure as the Japan arc. It is believed to be a rift block left over during crustal extension.

Tamaki et al. [1992] also suggested that oceanic spreading in the Japan basin involved a propagation of the

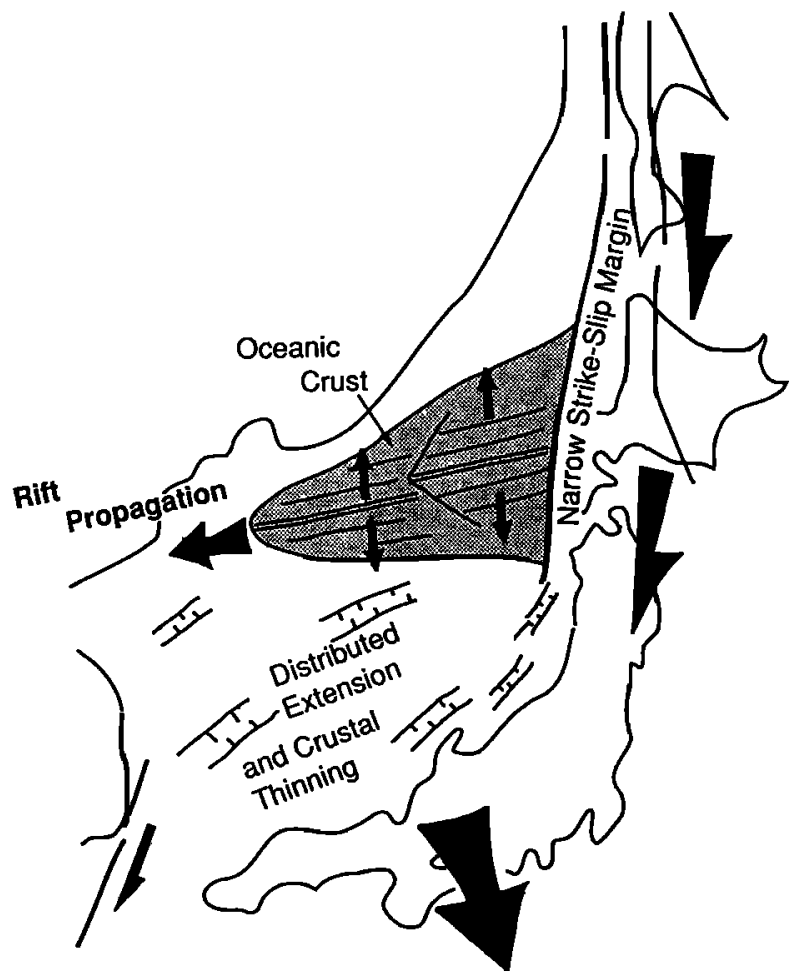

Figure 4. Simplified geometry of the Japan Sea opening after Jolivet and Tamaki [1992]. Distributed extension and oceanic spreading with westward propagation accommodate the southward motion of Japan along two major shear zones. 


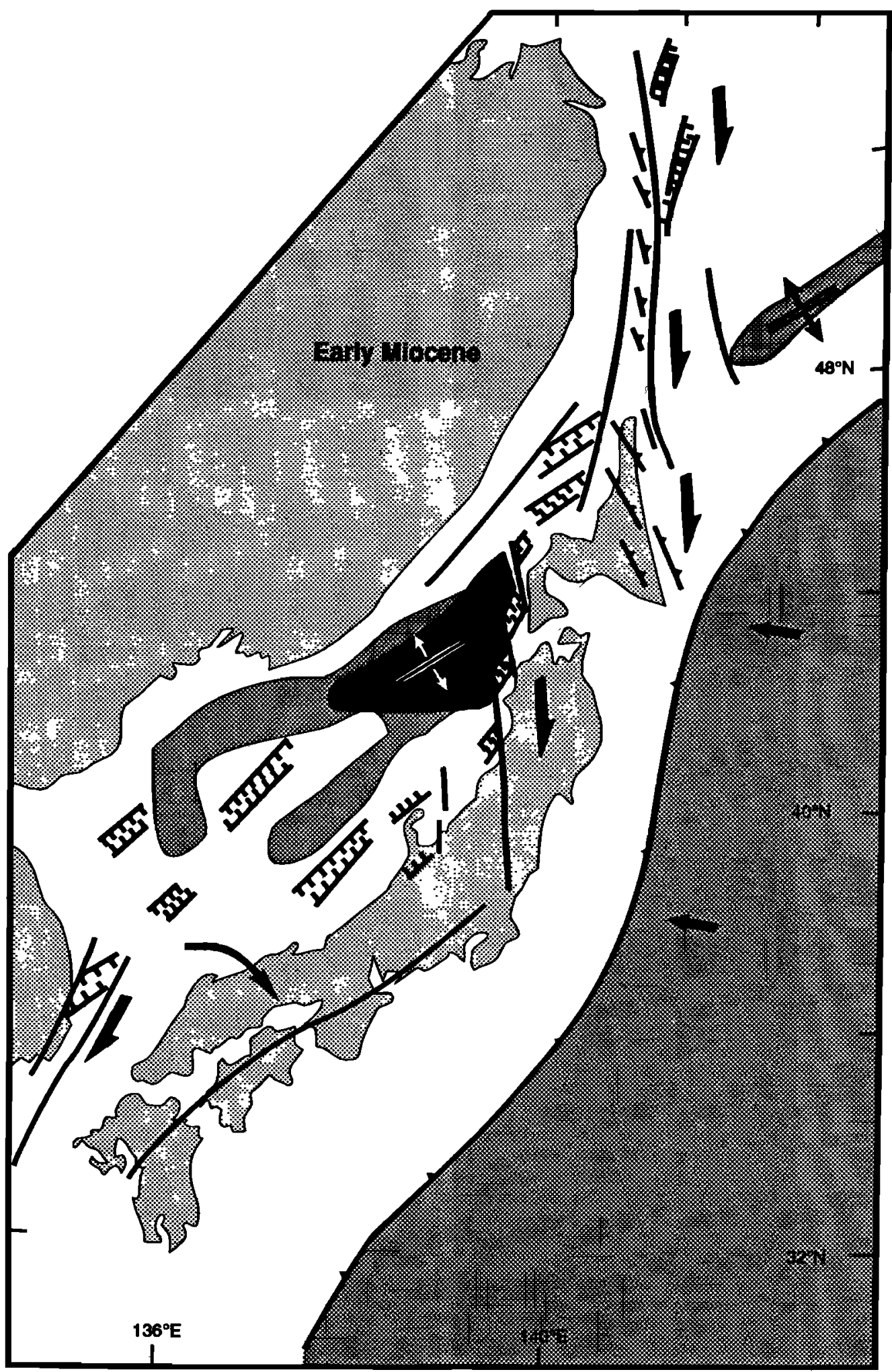

Figure 5. Reconstructions of the kinematics and tectonic context in the Japan Sea and Sakhalin region in the Miocene after Jolivet and Tamaki [1992].

spreading ridge toward the west, based on the geometry of magnetic anomalies. This is in good agreement with the general triangular shape of the oceanic domain: spreading has started earlier in the east where oceanic crust is more widely distributed.

Most geophysical data such as magnetic anomalies
[Tamaki and Kobayashi, 1988] or heat flow [Tamaki, 1986], as well as drilling results show that the Japan Sea opened in the early and middle Miocene between 25 and 15-12 Ma, as confirmed by tectonic and sedimentation histories of the basin and its margins [Tamaki, 1988; Tamaki et al., 1992; Jolivet al., 1991; Ingle, 1992]. 


\section{Miocene Tectonic Environment}

The geometry of opening is constrained not only by the internal structure of the basin but also by the tectonic evolution of its margins. As discussed by Jolivet and Tamaki [1992], there is a considerable difference between the eastern narrow strike-slip margin and the southern wide extensional one (Figure 4). As described by Lallemand and Jolivet [1985], Jolivet et al. [1992], and Tamaki et al. [1992], the eastern margin is the southernmost extension of a 2000-km-long strike-slip shear zone which extends from the northern tip of Sakhalin to central Japan (Figures 3 and 5). Sakhalin and Hokkaido are located along the transpressional branch of the dextral shear zone, which is characterized by major dislocations such as the Tym-Poronaysk fault in Sakhalin and the Hidaka shear zone in Hokkaido, as well as by en échelon folds and thrusts (Figure 6) [Fournier et al., 1994]. It is relayed to the south at the latitude of Hokkaido by a transtensional branch, which bounds the Japan Sea back arc basin to the east. A second dextral shear zone is found between Korea and Japan in the Tsushima Strait [Sillitoe, 1977]. These two shear zones were active in the late Oligocene (or earlier) until the middle Miocene contemporaneous with opening in the back arc region [Jolivet et al., 1991]. The shear zone seems to control sediment deposition in pull-apart basins in the Tartary Strait (H.S. Gnibidenko et al., unpublished data, 1990), or along the eastern margin of the oceanic domain, or again along the east coast of Korea. The direction of the maximum horizontal principal stress during the Miocene was NE-SW in the whole Japan Sea as well as along its margins [Otsuki, 1989; Jolivet and Huchon, 1989; Jolivet al., 1992; Charvet et al., 1992]. The general geometry is that of a large pull-apart basin, as suggested earlier by Lallemand and Jolivet [1985] and Kimura and Tamaki [1986]. Formation of en échelon grabens along the eastern margin of the Japan Sea lasted during the early Miocene until the middle Miocene (see Figure 8) [Suzuki, 1989; Yamaji, 1989; Amano and Sato, 1989] and was contemporaneous with dextral shear along the Hidaka Shear Zone [Jolivet and Huchon, 1989].

Figure 7 [after Ingle, 1992] shows the timing of subsidence in the Japan Sea and along its margins, based on sedimentation history of several drill holes around and inside the basin. It shows that the history of subsidence started around $30 \mathrm{Ma}$ and lasted until $10 \mathrm{Ma}$, after which uplift of the margins is recorded. This timing is in fair agreement with that deduced from the study of brittle deformation in Hokkaido by Jolivet and Huchon [1989], who showed that E-W compression replaced dextral strike-slip shear at the end of the middle Miocene (Figure 8). The inception of compression occurred $8 \mathrm{~m}$.y. ago before compressional deformation became localized along the eastern margin, leading to the seismicity observed today. The high rate of subsidence is also in agreement with the pull-apart hypothesis [Ingle, 1992] as is the geometrical relation between the eastern shear zone and the oceanic domain.

Jolivet and Tamaki [1992] interpret the oceanic domain as a large tension gash at the end of a strike-slip shear zone (Figure 4). As the reconstructions will show below, crustal extension was distributed in the Miocene in

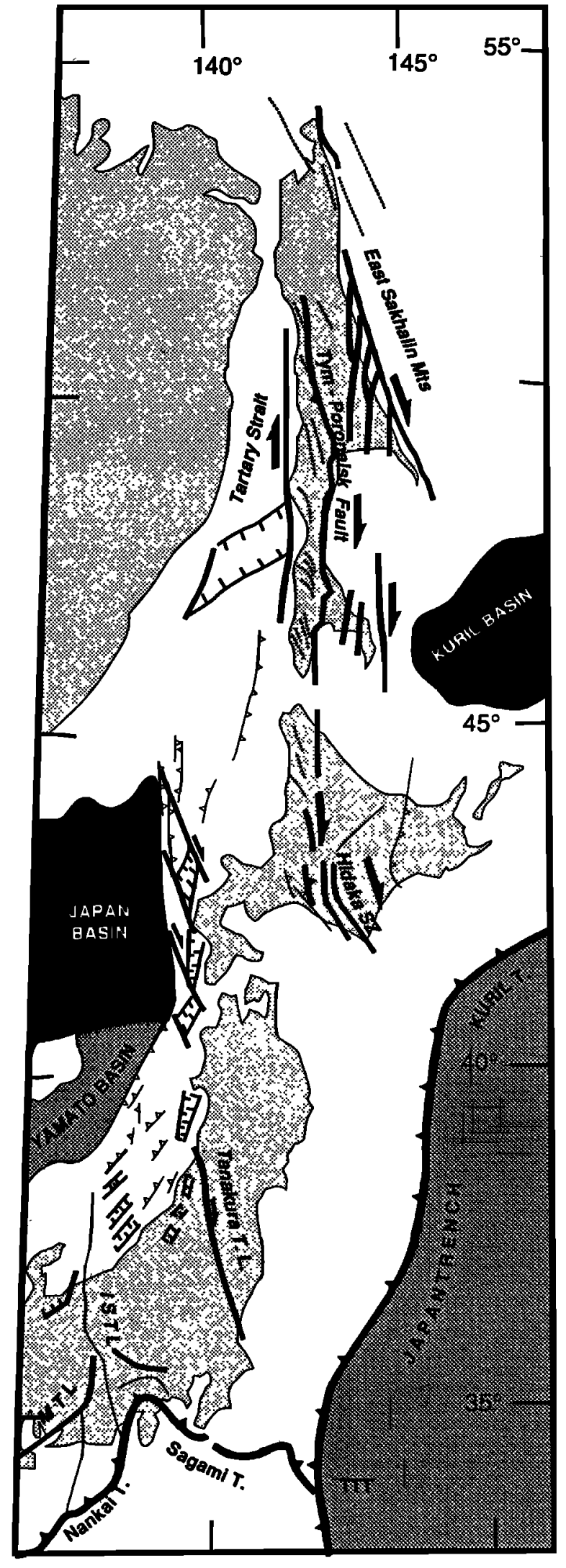

Figure 6. Main features of the dextral shear which guide the opening of the Japan Sea to the east. Thick lines represent the strike-slip structures, and thinner lines the present-day compressional ones. Dotted lines show the main en échelon folds in Sakhalin. 


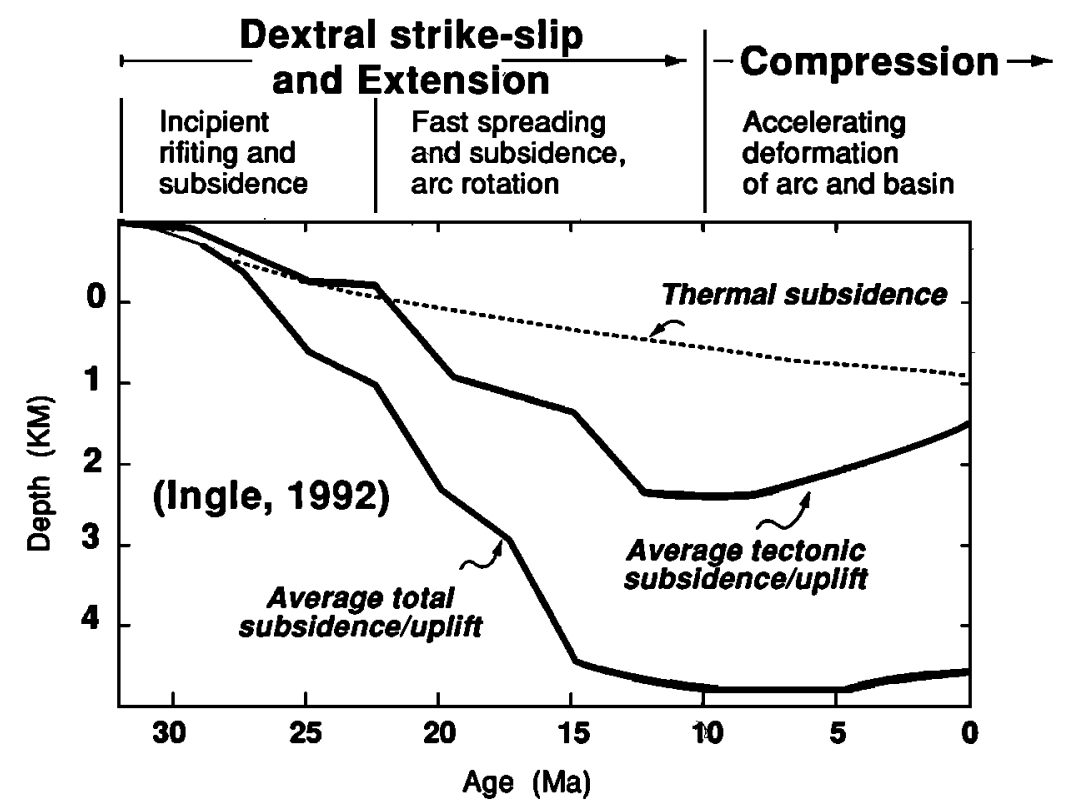

Figure 7. Subsidence curve in the Japan Sea after Ingle [1992].

a wide area bounded by two dextral shear zones, and oceanic spreading started in a limited zone next to the eastern shear zone. Lithospheric breakup was localized where extensional and strike-slip deformations coexisted, e.g., where the maximum of strain rates is expected. Tamaki et al. [1992] emphasized that it might be a general rule that oceanic spreading in back arc basins starts along strike-slip faults.
Back arc opening was claimed to have been contemporaneous with rotations about vertical axes of the Japan arc [Otofuji and Matsuda, 1983, 1984, 1987; Otofuji et al., 1985, 1991]. As shown by Figure 9, counterclockwise rotation of NE Japan lasted about as long as back arc opening proceeded (see references to the original data in Figure 9 caption). In SW Japan instead, clockwise rotation seems instantaneous toward the end of

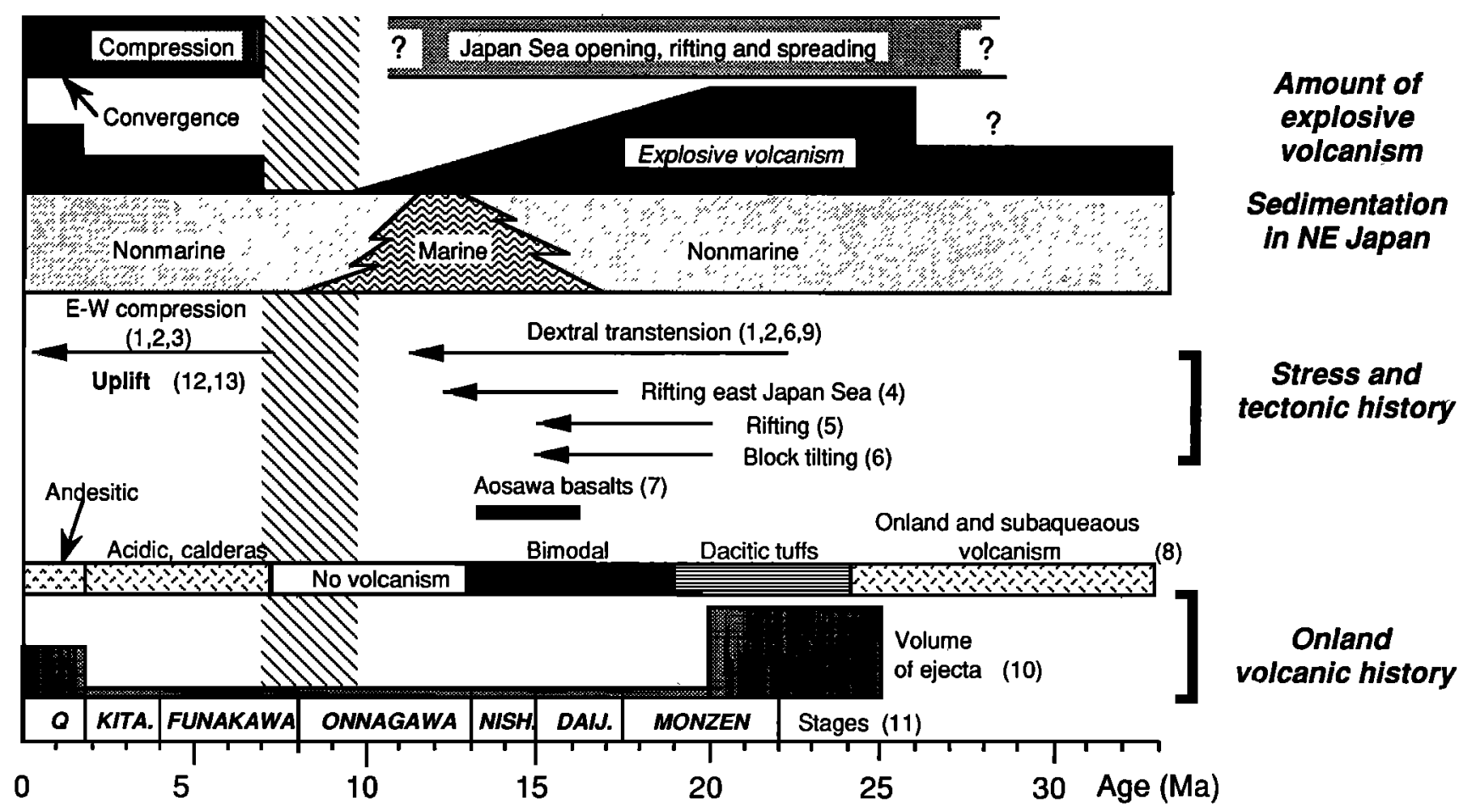

Figure 8. Synthesis of the tectonic and volcanic events in northeast Honshu after (1) Jolivet and Huchon [1989], (2) Jolivet et al. [1990], (3) Nakamura and Uyeda [1980], (4) Suzuki [1989], (5) Yamaji [1989], (6) Amano and Sato [1989], (7) Tsuchiya [1989], (8) Usuta [1989], (9) Otsuki [1989], (10) Sugimura et al. [1963], (11) Fujioka [1986], (12) Sugi et al. [1983], and (13) Iijima et al. [1990]. 


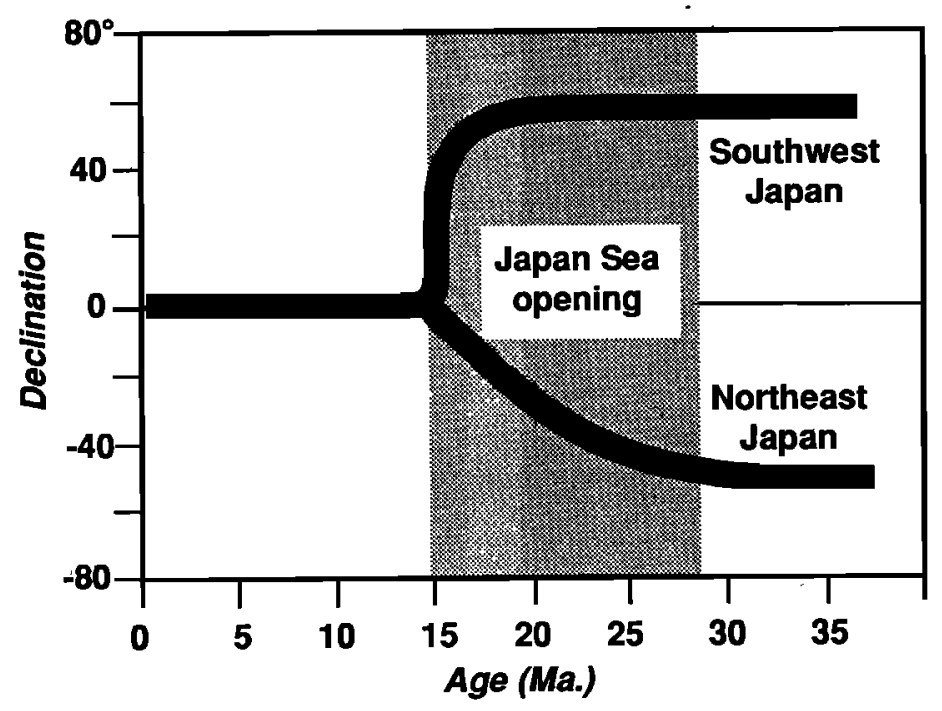

Figure 9. Rotation path for southwest and northeast Japan and the period of Japan Sea opening versus age compiled from Otofuji et al. [1991], Hayashida et al. [1991], Hayashida [1986], Otofuji and Matsuda [1983], Otofuji and Matsuda [1984], Otofuji and Matsuda [1987], Otofuji et al. [1985], and Tosha and Hamano [1988].

the opening time span. This last observation had led Otofuji et al. [1985] to postulate an instantaneous opening of the Japan Sea by rigid rotation of SW Japan about 15 Ma. This situation would have led to the formation of oceanic crust around $15 \mathrm{Ma}$ in the whole Japan Sea. Recent drilling [Tamaki et al., 1992] showed instead that the basin is everywhere older than the middle Miocene. There is so far no definite explanation to this discrepancy, but it is likely that local rotations of dominos played an important part in the story as suggested by Kanaori [1990] and Kodama and Nakayama [1993].

\section{Correlations of Arc Volcanism and Tectonics}

Besides correlations between the subsidence and tectonic evolution, a clear contemporaneity of volcanic and tectonic episodes can be drawn out of an analysis of offshore ash layers and onland volcanic deposits [Jolivet and Tamaki, 1992]. Arc volcanism in Japan experienced two stages of activity from the late Oligocene, separated by one quiet episode between 10 and $7 \mathrm{Ma}$ (Figure 8). This short period is seen in the ash record of numerous drilling sites around Japan, on the Pacific side as well as on the Japan Sea side of the arc.

The first episode corresponds to the rifting and spreading of the Japan Sea. In the late Oligocene and early Miocene (Green Tuffs period) the volcanic products of extensive explosive volcanism are found on land on either side of the Japan Sea. As is true of most back arc basins [Taylor, 1992], the Japan Sea early rift was located along the volcanic arc, in a manner similar to the active intraarc rifting of the Bonin arc. The end of the opening is marked by a distinctive period of basaltic volcanism along the eastern margin (Aosawa Basalts [Tsuchiya, 1989]). A period of no volcanic activity is recognized on land between 13 and $8 \mathrm{Ma}$ [Cadet and Fujioka, 1980; Usuta, 1989]. The timing of offshore ash layers allows us to shorten this period to 2-3 m.y., between 7 and $10 \mathrm{Ma}$. This period correlates to the transition between opening and inception of compression, after which, acidic explosive volcanism resumed in the form of large-scale calderas, until $2 \mathrm{Ma}$, when the present-day andesitic volcanism started [Usuta, 1989; Yahata, 1989; Ito et al., 1989]. This transition from explosive acidic volcanism to andesitic volcanism was interpreted by Jolivet and Tamaki [1992] as an effect of the localization of compressional deformation along the eastern margin at $2 \mathrm{Ma}$ : the compressional stress field which prevailed before made the ascent of magma through the upper crust difficult. Magma had to accumulate in magma chambers, where it could differentiate, and made its way in an explosive manner, forming large calderas. Once deformation had been localized along the eastern margin, compressional stress was reduced through the arc, and the ascent of magma made easier.

The volcanic front migrated during this evolution, as is well documented by Ohguchi et al. [1989]. This migration can also be explained in a simple way in the same tectonic timing. During the opening, the volcanic front migrated first eastward by $200 \mathrm{~km}$ with respect to its present position between 30 and $20 \mathrm{Ma}$, and then came back progressively to its present position, which it reached about $12 \mathrm{Ma}$ [Ohguchi et al., 1989]. These displacements were interpreted as indications of variations of the slab dip angle through time [Tatsumi et al., 1989]. It is, however, possible to interpret it more simply, taking into account the thinning and stretching of the arc crust during rifting and spreading of the Japan Sea. If one assumes, contrary to Tatsumi et al. [1989], a constant dip angle of the subducting slab through time, and that the volcanic front corresponds to a constant depth of the slab, one can then use the displacement of the volcanic front to estimate to thinning history of the arc, as the distance between the trench and the active volcanic front at any given time must remain constant. As shown by Figure 10, homogeneous stretching of the upper plate crust leads to a displacement of the volcanic arc oceanward with respect to its previous position. The distance between the two volcanic fronts 


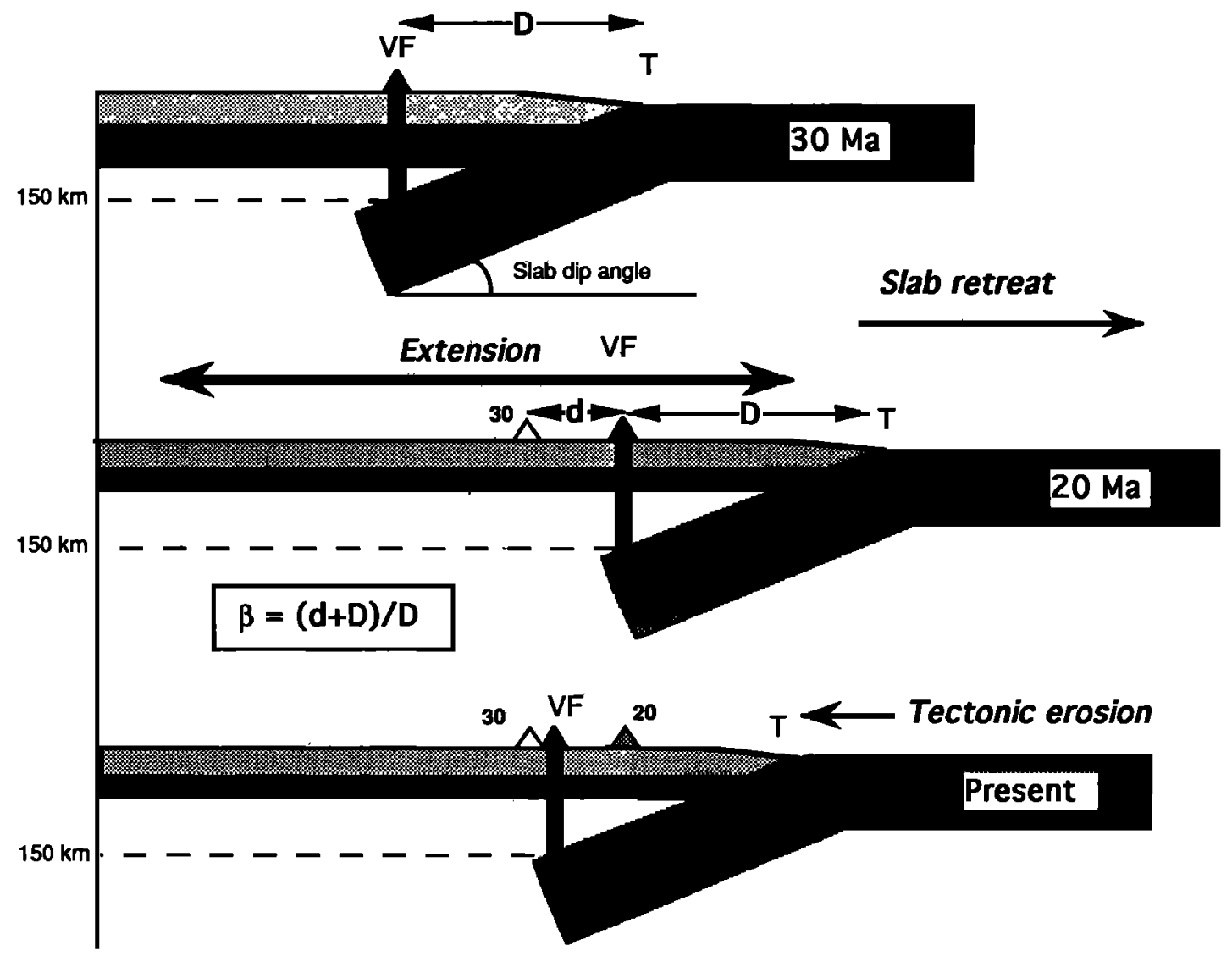

Figure 10. Migration of the volcanic front from $30 \mathrm{Ma}$ to the present. VF, volcanic front; T, trench; D, distance between volcanic front and trench; d, distance between the 20-Ma and 30-Ma volcanic fronts. During the rifting period, homogeneous stretching of the arc lithosphere is assumed. D is kept constant through time because the slab geometry is supposedly constant (modified after Jolivet and Tamaki [1992]).

before and after stretching depends only upon finite extension $\beta$. A displacement oceanward of $200 \mathrm{~km}$, as described in Ohguchi et al. [1989], leads to a finite homogeneous stretching factor of 1.8 , which is a reasonable value compared to longitudinal variations of crustal thickness within arcs where extension is active, such as the Bonin arc. The subsequent retreat of the volcanic front toward its present position can be interpreted as the result of tectonic erosion as discussed by Von Huene and Lallemand [1989] (Figure 10]. This simple explanation does not exclude the possibility of variations of the slab dip angle, but it shows that internal deformation of the arc during the rifting episode has to be taken into account as well as deep-seated phenomenas which are by nature more difficult to observe and to test.

This hypothesis needs to be tested, and the simplest way would be to quantify the amount of late Oligocene extension from faults offset. Given the thick late Neogene and Quaternary cover of NE Japan, late Oligocene deformation might not be easy to observe. It is very likely anyway that during the Japan Sea rifting, extension was not localized only in the back arc region, but rather encompassed the entire width of the arc until the forearc region, as illustrated by the present-day structure of the Bonin arc.

\section{Tectonic History}

We now present tectonic reconstructions which are based on the kinematics described by Jolivet et al. [1991] and Jolivet and Tamaki [1992] (Figures 11a to 11f). The Japan arc is divided into several rigid blocks which move along two master strike-slip faults, described above, and rotate about vertical axes. As suggested by Jolivet et al. [1991], the transtensional regime which prevailed in the Miocene in the back arc domain favored clockwise rotations, while the transpressional regime in the north instead favored counterclockwise rotations. A larger dextral slip is accommodated along the eastern shear zone than along the western one, and the difference is accommodated by dextral rotation of southwest Japan. Northeast Japan also rotates counterclockwise in response to the transpressional context in Hokkaido. When one closes back the oceanic domain of the Japan basin, moving back the Japan arc toward the north, a small triangular region remains where oceanic accretion has started. Figure $11 \mathrm{f}$ shows the position between 25 and $30 \mathrm{Ma}$ (drawn at $30 \mathrm{Ma}$ ) when we assume the earliest oceanic crust was formed (An 7). The scheme is the following: a wide domain of distributed extension accommodates the transition between two major strike-slip shear zones. At 

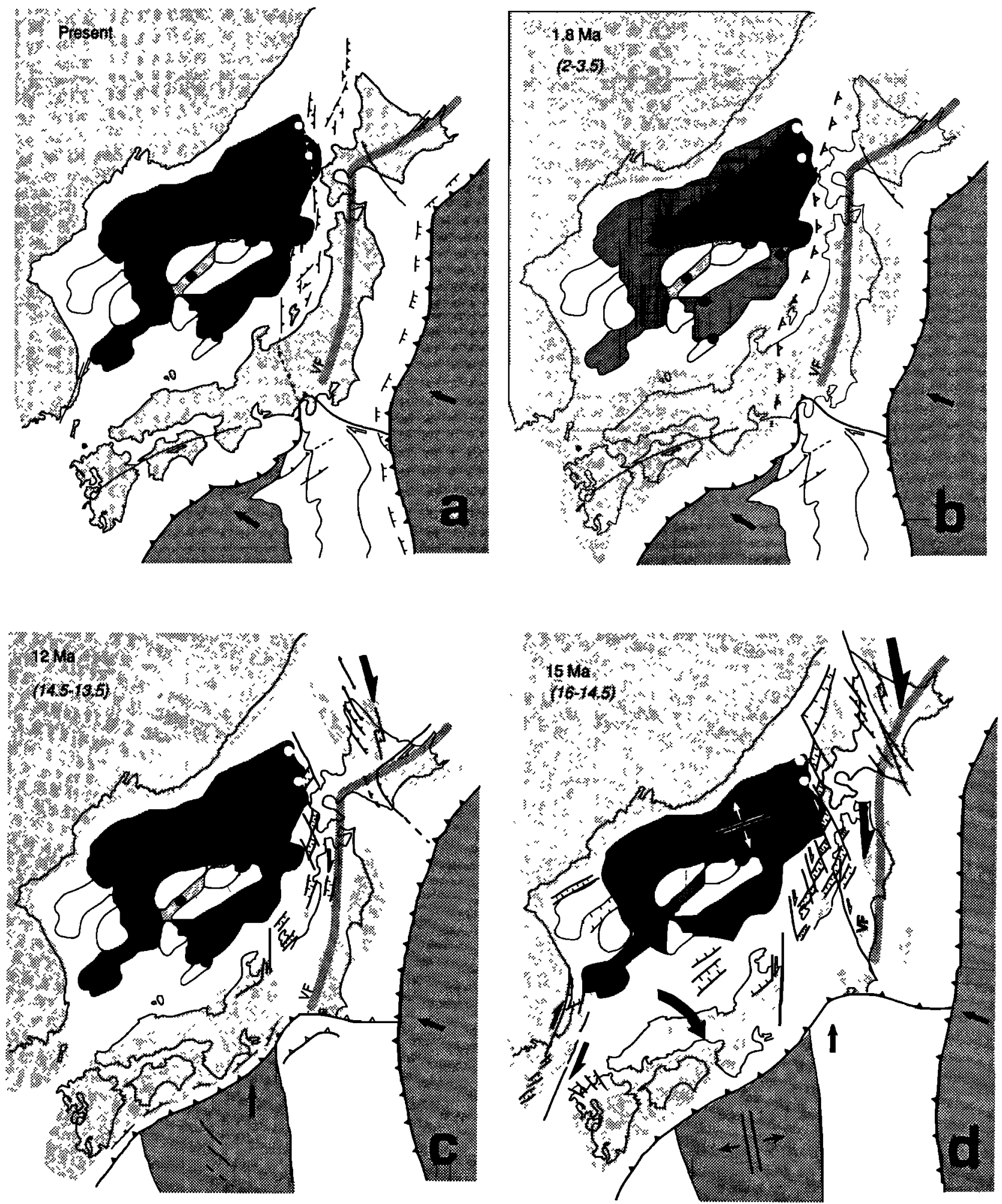

Figure 11. Reconstruction of the tectonic evolution of the Japan Sea. Kinematics after Jolivet et al. [1991] and Jolivet and Tamaki [1992]. Numbers in parentheses are the intervals relevant to the coastlines taken from Iijima and Tada [1990]. Light shading represents the onshore regions, white areas anre below sea level. Dark shading in the Japan Sea represents the region of distributed stretching, and the black area the domain of oceanic crust. Solid dot represents freshwater lakes. VF is the volcanic front after Ohguchi et al. [1989]. 


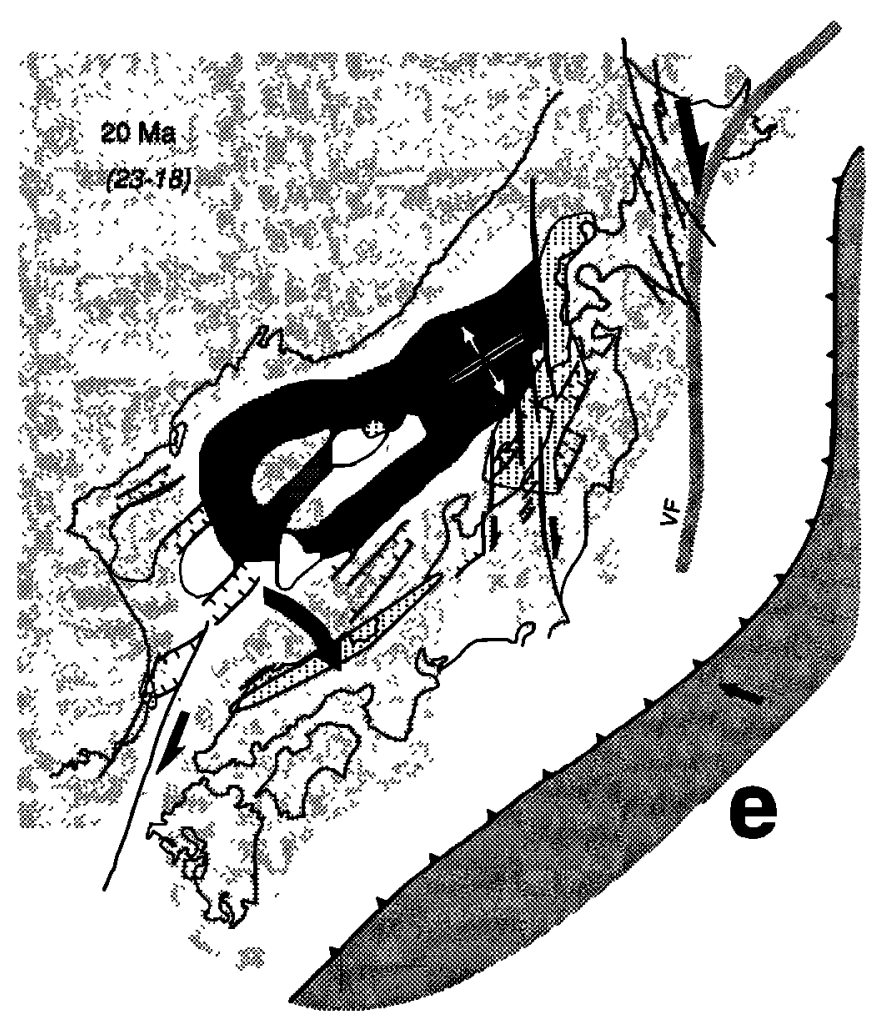

Figure 11. (continued) the junction between the eastern shear zone and the domain of distributed extension, high shear strains lead to a complete rupture of the lithosphere and formation of oceanic crust. The newly formed oceanic ridge then localizes most of the relative displacement in the extensional domain. Farther west, crustal stretching accommodates the southward motion of SW Japan. Note that the formation of oceanic crust occurs at the transition between transpressional and transtensional regimes.

Coastlines have been drawn on the reconstructions based on the work by Iijima and Tada [1990], who compiled stratigraphic and sedimentological data in and around the Japan Sea. We take from their compilation, only coastlines which are sufficient to illustrate the geometry of basins and discuss the first-order sedimentological history in relation to tectonic events.

On the $30 \mathrm{Ma}$ (Figure 11f) reconstruction, most of the Japan arc is above sea level except for the outer zones of SW Japan, where an accretionary prism is being built in the proto-Nankai trench, as well as for the central part of Hokkaido, where coarse clastics fill narrow N-S trending basins parallel to the Hidaka shear zone. Freshwater lakes are described on the mainland. Dextral motion along the two major shear zones was transferred to distributed extension in the Yamato basin and oceanic spreading in the Japan basin.

Around $20 \mathrm{Ma}$ (Figure 11e) the Japan and Yamato basins were fully separated and below sea level. The entire Hidaka shear zone has gone above sea level. Migration of the volcanic front far east of its present position is taken as an indication of distributed rifting within the Japan arc, as

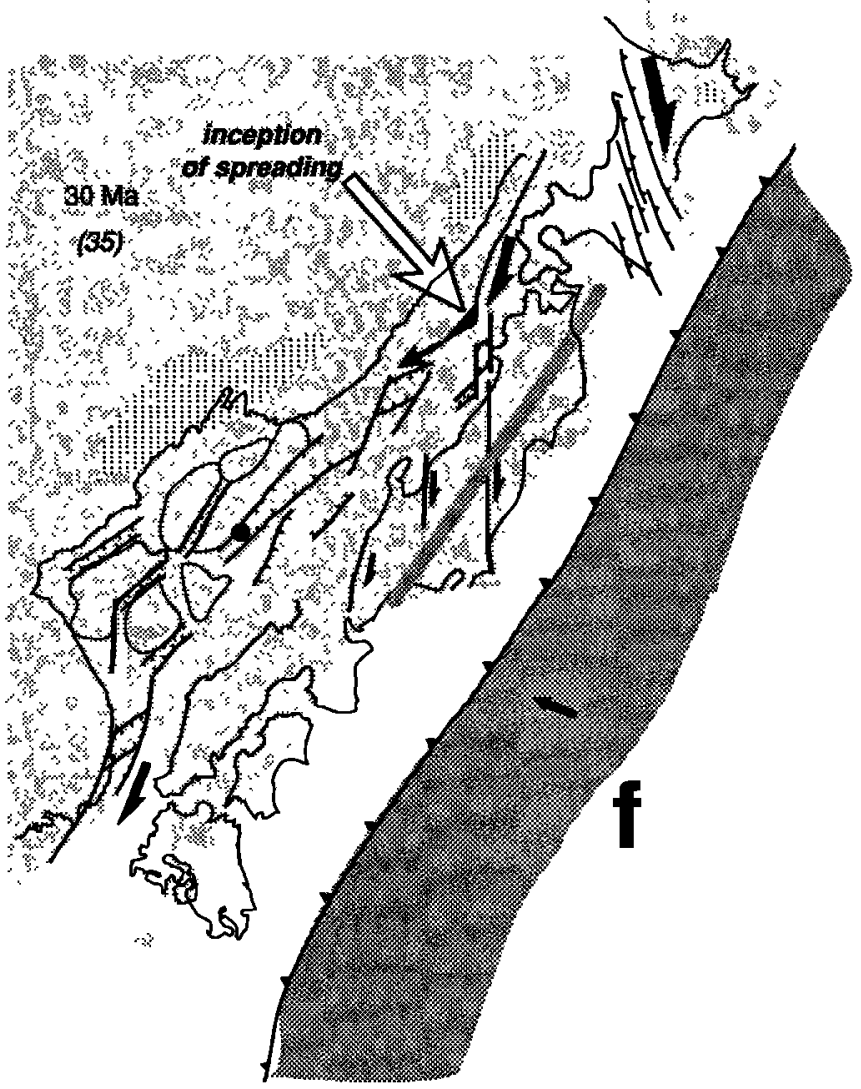

discussed above. Active oceanic spreading enlarges the oceanic domain with a westward propagation of the spreading center. Distributed extension deepens the Yamato basin and the western extension of the Japan basin as shown on the subsidence curves of Ingle [1992]. Two zones of fresch waters characterize the domains of active intraarc transtension (west of Tohoku) or pure extension (SW Japan). The Fossa Magna starts to be seen as a narrow N-S trending basin parallel to the major shear zones, and separates SW and NE Japan. The arcuate shape of Japan appears progressively. The outer zones of SW Japan (Shimanto belt) emerged at this time. Charvet and Fabbri [1987] attribute this event to compressional deformations, which they relate to a collision event in the early Miocene. In their reconstructions, they use the Philippine Sea plate (PHSP), which carries high standing features such as the Palau-Kyushu ridge and the Bonin arc as well as the Shikoku basin spreading center as a collider. This is in contradiction with the timing of our reconstructions of the motion of the PHSP, which lead to a more recent subduction and collision of the PHSP under SW Japan. In a recent study of the paleomagnetic rotation of the PHSP, Haston and Fuller [1991] concluded to even more recent collision of the Bonin arc with SW Japan around $10 \mathrm{Ma}$. If the deformation in Shimanto is not due to the collision of the PHSP, it must involve buoyant features carried by the Pacific plate.

About $15 \mathrm{Ma}$ (Figure 11d) the opening was almost complete. The last increments of oceanic spreading are recorded, while rotation and strike-slip motion are still active. The arc has now reached its present shape, and 
most of it is below sea level with the notable exception of the Hidaka shear zone, which remains an elongated high ground, and a narrow stripe in SW Japan which is perpendicular to the direction of extension. The N-Strending Hidaka Mountains are flanked on both sides by narrow, shallow marine basins filled with coarse clastic deposits. The shape of the basin to the east is controlled by dextral strike-slip faults [Miyasaka et al., 1986]. The western part of SW Japan, most of the Shimanto belt, is above sea level. The present-day plate configuation of the trench-trench-trench (T-T-T) triple junction is established around this time also, and collision of the Bonin arc with central Japan begins. At the same time, the last increments of spreading are recorded in the Shikoku basin.

The period at $12 \mathrm{Ma}$ (Figure 11c) is when most strikeslip motion has stopped and will soon be replaced by E-W compression in NE Japan. The emerged domain of SW Japan has progressed toward the east and is starting to close the Fossa Magna. This might be an effect of the progressive eastward displacement of the Bonin arc during its collision with southern Japan. The western side of NE Japan is still below sea level, as is the central part of Hokkaido. Between 10 and $2 \mathrm{Ma}$, a compressional stress field prevailed in NE Japan, and this led to the progressive uplift of the arc in Honshu and Hokkaido.

At 2-3 Ma (Figure 11b), only the westernmost part of NE Japan was below sea level before the inception of the active deformation zone localized along the eastern margin of the Japan Sea. This led to the final uplift of this narrow stripe in the Recent period. The entire SW and central Japan has been uplifted as well, and intraoceanic thrusts formed south of the collision zone inside the PHSP.

These reconstructions, which show good correlations of tectonic, volcanic, and sedimentological events, also allow a crude quantification of the dextral displacement along the major strike-slip faults. We assume that the south-to-north finite motion of NE and SW Japan with respect to Asia between 30 and $12 \mathrm{Ma}$ has been entirely taken up further north along the more localized dextral shear zone which runs along Sakhalin and in the Tartar Strait. This leads to a finite dextral motion of about 400 $\mathrm{km}$. Given the uncertainties of the reconstructions, which are difficult to quantify, one can reasonably conclude that several hundreds of kilometers have been accommodated along this shear zone, which makes it a first-order feature of the finite deformation of Asia. The western shear zone in the Tsushima Strait has accommodated a smaller displacement of the order of $200 \mathrm{~km}$, the difference being taken up by rotation of SW Japan.

We thus conclude with the following scheme: several large-scale intracontinental dextral shear zones run N-S oblique to the eastern margin of Asia, which is subjected to back arc extension. Asymmetric back arc spreading occurs where the dextral shear zones intercept the region of back arc extension and control the geometry of opening, as described above. The question then is the cause of these dextral shears in eastern Asia. Kimura and Tamaki [1986] and Jolivet et al. [1990] suggested earlier that they are consequences of the India-Asia collision. Back arc extension, on the other hand, occurred in the whole western Pacific region in the same period, late Oligocene to the middle Miocene. We shall discuss separately the two phenomenas, back arc spreading and collision, in the following and see the respective roles they played in the Japan Sea history.

\section{Japan Sea and Contemporaneous Oceanic Basins in the West Pacific}

Major back arc basins of the western Pacific region opened in a short time span bracketed between 30 and 10 Ma (see the compilation by Park et al. [1990]). Three large basins are settled in the eastern margin of Asia. The Kuril basin (Figures. 1 and 2) opened between 15 and 30 Ma, according to Kimura and Tamaki [1985], north of the Kuril arc in a triangular domain with one side along the Sakhalin-Hokkaido shear zone. Its age of opening is certainly the less well controlled and is based mostly on the tectonic and sedimentological evolution of its margins in Japan and Sakhalin, which are very similar to that of the Japan Sea. The South China Sea has been studied in greater detail and reveals a consistent pattern of magnetic anomalies. The first interpretations by Taylor and Hayes $[1980,1983]$ provided an age of opening between 32 and $17 \mathrm{Ma}$, based on the identification of anomalies 11 to $5 \mathrm{~d}$. More recently, Briais et al. [1993], based on a new set of data (Figure 12), recognized anomaly $5 \mathrm{c}$ and concluded that the opening occurred between 32 and $15 \mathrm{Ma}$. Extension predated spreading along the southern margin of China and started as early as the Paleocene [Ru and Pigott, 1986]. The Sulu Sea was recently dated by drilling of the early and middle Miocene [Rangin et al., 1990a; Rangin and Silver, 1991]. Rangin et al. [1990b] showed that the Sulu Sea was formed inside the margin of Eurasia and not as a trapped basin, as suggested by Lee and $M c$ Cabe [1986]. Oceanic spreading in these four large basins thus occurred in the same period on the margin of Eurasia, and was preceded by several million years of intracontinental rifting. This observation shows that from the Paleocene to the middle Miocene, the entire eastern margin of Asia was subjected to extensional stress conditions.

Two large basins formed in the same period along the eastern border of the PHSP, the Shikoku and Parece Vela basins (Figure 2), which are part of the largest back arc basin in the world and formed behind the Bonin-Mariana trench system. Mrozowski and Hayes [1979] recognized magnetic anomalies 10 to $5 \mathrm{~d}$ and concluded that the opening occurred between 30 and $17 \mathrm{Ma}$ for the Parece Vela basin. The age of the Shikoku basin is more certainly known, based on several drill holes [de Vries Klein and Kobayashi, 1980] which reached oceanic crust and identification of magnetic anomalies [Shih, 1980; Chamot-Rooke et al., 1987] (also, N. Chamot-Rooke et al., Magnetic lineation and paleomagnetism in the Shikoku basin: Implications for the Miocene kinematics of the Philippine Sea plate, submitted to Geophysical Journal International, 1993; hereinafter referred to as submitted manuscript, 1993). Anomalies 7 to 5b suggest an opening between 27 and $13 \mathrm{Ma}$ (Figure 12). Opening started along the paleo-Bonin arc and separated the present-day Bonin arc and the remnant Palau-Kyushu ridge. It probably started with rifting along the volcanic arc, as is seen today in the Bonin arc [Taylor, 1992]. Extension and spreading also continue in the Mariana trough east of the Parece Vela basin. 


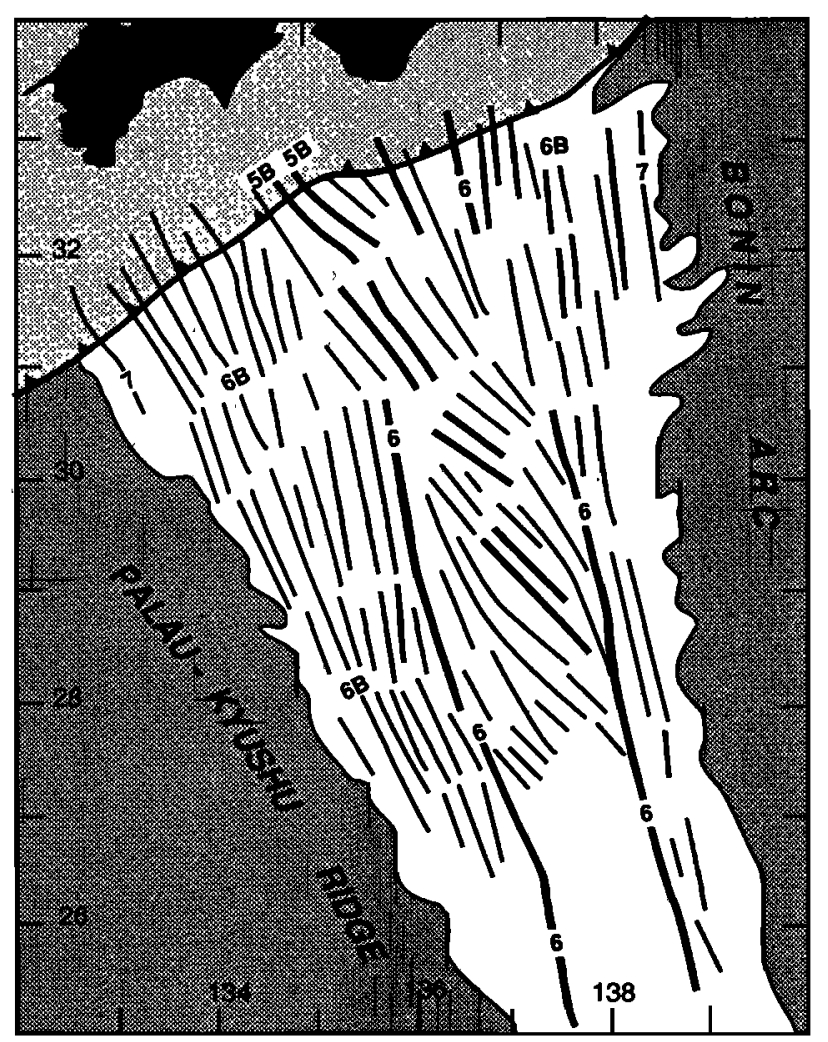

SHIKOKU BASIN (CHAMOT-ROOKE ET AL. 1993)

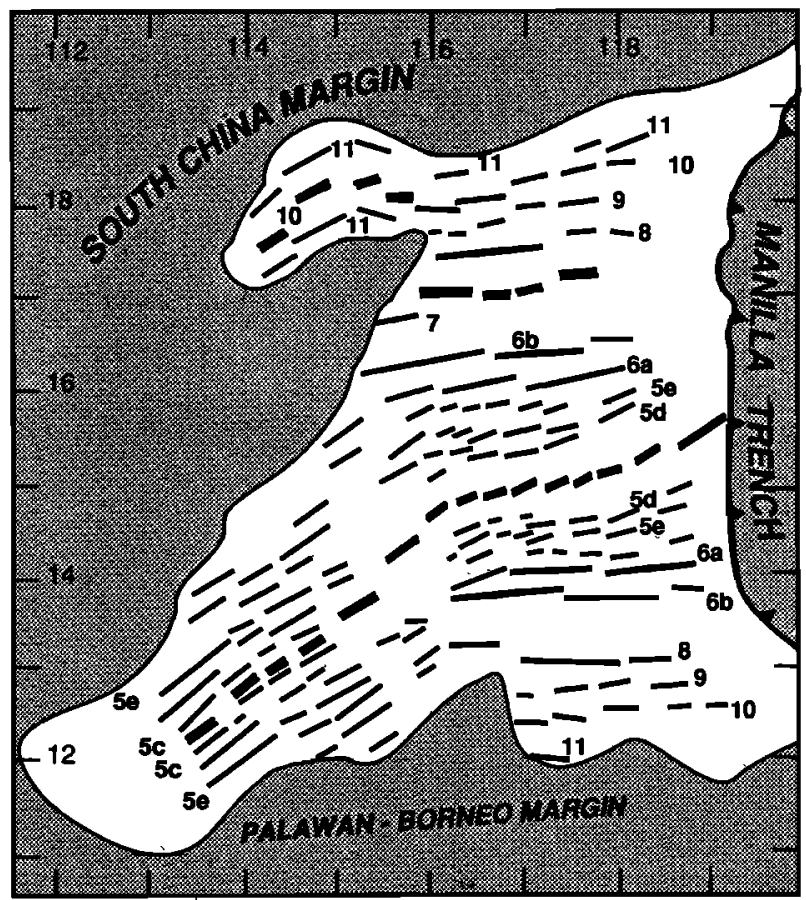

SOUTH CHINA SEA (BRIAIS ET AL. 1993)

Figure 12. Magnetic anomalies in the Shikoku basin and South China Sea (after N. Chamot-Rooke et al., submitted manuscript, 1993; Briais et al. [1993]).

While the Japan Sea, South China Sea, Kuril basin, and Sulu Sea were in the process of opening, a large back arc basin was formed along the eastern margin of the PHSP. Figure 12 shows the magnetic anomaly pattern of the two best surveyed basins, the Shikoku basin and the South China sea (after N. Chamot-Rooke et al., submitted manuscript, 1993) [Briais et al., 1993]. Though spreading started earlier in the South China Sea, it stopped at the same time after Anomaly $5 \mathrm{c}$ in both basins and a similar kinematic reorganization occurred by counterclockwise rotation and segmentation of the ridge around An 6 (20 $\mathrm{Ma}$ ). The contemporaneity of opening and intimate evolution of these two basins suggests that a common process created extension and spreading. As it affects the eastern margins of the Eurasia plate and PHSP, we believe that this process is not related to the India-Asia collision, which would not affect the PHSP. However, the largescale strike-slip shear zones which control rifting and spreading in the Japan Sea as well as in the South China Sea, if one follows the model proposed by Tapponnier et al. [1982], cannot be simply explained by back arc spreading.

\section{Japan Sea and the Deformation of the Asian Continent}

Variations of crustal thickness in Asia can be visualized by the topographic map of Figure 2. The area of crustal thickening encompasses the Tibetan plateau and the Himalayas, the Karakoram-Pamir region, and Tien Shan and Altaï ranges. These regions of high topography are bounded by distinctive large-scale structures, such as the Altyn-Tagh fault or Longmen Shan thrust zone. Regions of crustal thinning are the Andaman Sea, South China Sea, Gulf of Thailand, and Sulu and Celebes Seas. The Ryukyu back arc region (Okinawa basin) extends in the East China Sea and the north China grabens and further to the northeast, to the Japan and Okhotsk Seas. The Baikal rift is the westernmost extensional region. All these rifting events started during the Paleogene after the collision, and those rifts closest to the thickened crust are still active (Baikal, North China Grabens, Andaman Sea). All but the Okinawa basin are now extinct (Kuril basin) or in a closing stage (South China Sea, Japan Sea). Those still active along subduction zones face normal oceanic lithosphere which subducts freely beneath the western part of the Sunda arc or beneath the Ryukyu arc. The South China, Sulu, and Celebes Seas started to close when the collision of Australia with Indonesia occurred [Rangin et al., 1990], and Japan Sea rifting was reverted to compression when the Bonin arc collided with central Japan.

Jolivet et al. [1989] and Rangin et al. [1990b] explored previously the tectonic evolution of the eastern margin of Asia in two sets of reconstructions. The first showed the entire northwest Pacific region, putting emphasis on the Japan Sea and the PHSP [Jolivet et al., 1989], and showed the Indonesian region only crudely. 


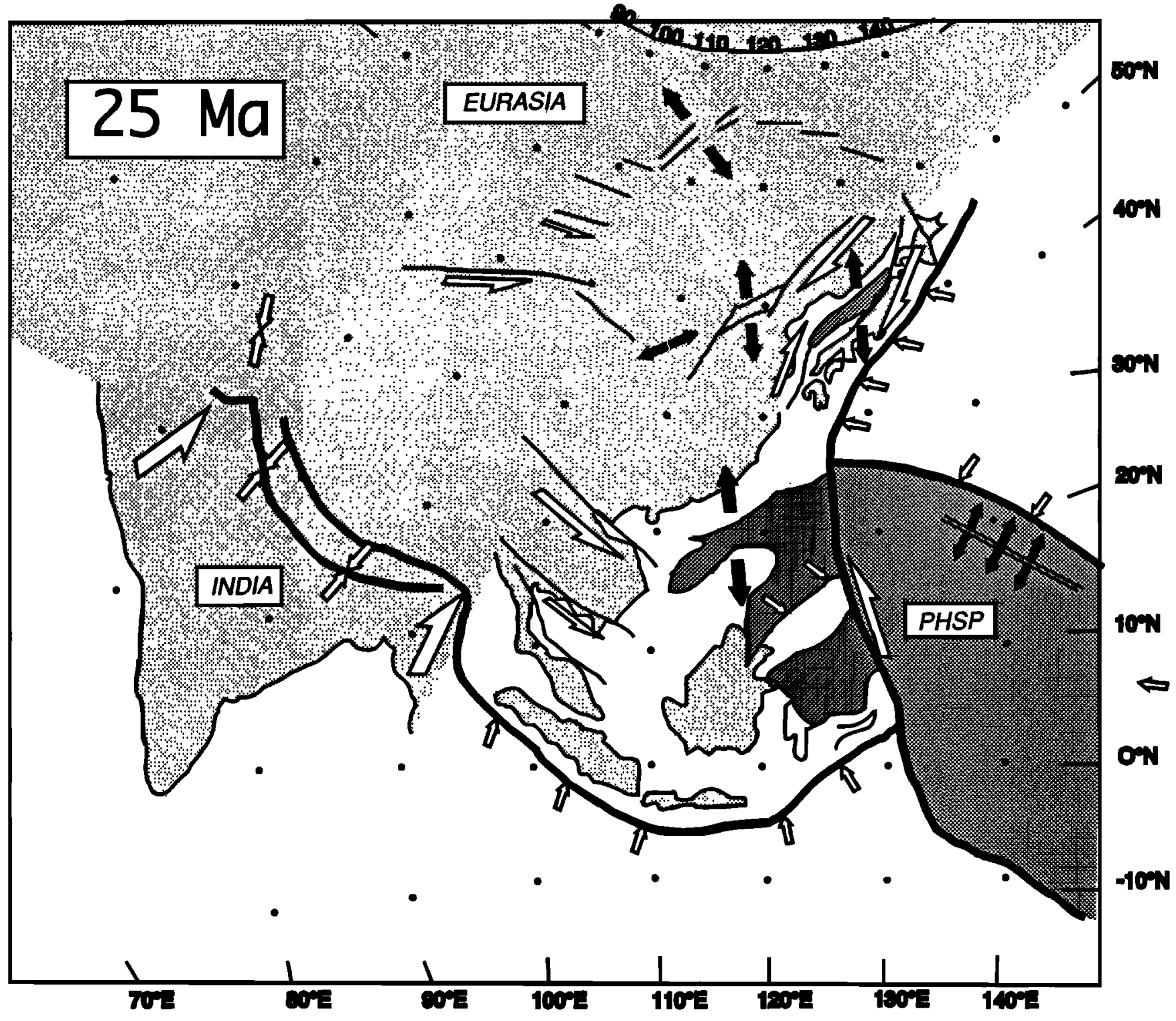

Figure 13. Reconstruction of Asia and west Pacific at $25 \mathrm{Ma}$ (early Miocene). See Figure 1 for explaination of symboles.

More precise reconstructions were made by Rangin et al. [1990b]. Precise age constraints came through ODP leg 124 in the Sulu and Celebes Seas [Rangin et al., 1990a]. We can use these reconstructions to obtain a crude image of the finite displacement of the eastern and southeastern borders of Asia, with respect to fixed Eurasia. The geometry that we obtain can be used to illustrate the general evolution of the boundaries of Asia during its collision with India. They certainly are not precise because uncertainties on the total displacement along major faults inside Asia are very large. Only the general scheme matters for our discussion (Figures 13 and 14).

Rangin et al. [1990b] proposed reconstructions of the Philippines and Indonesian region from the Eocene to the Present, describing deformation of the region where the Pacific, Philippine Sea, Australia, and Eurasian plates meet. Complex deformation is distributed over a large area [Hamilton, 1979], where a number of marginal basins opened in the Oligocene and Miocene and then started to close along subduction zones, such as the Manila or Sulu trenches [Rangin and Silver, 1991]. The motion of major plates around the deformed domain was taken from the global kinematic data set [Stock and Molnar, 1982], which provided a general framework. Various kinds of data were used for the reconstructions. The geometry of opening of the South China Sea is constrained by a set of well-defined magnetic anomalies, as described above. Recent data, obtained by drilling in the Sulu and Celebes Seas, provided age constraints for the opening of these basins [Rangin et al., 1990a; Silver and Rangin, 1991a; Rangin and Silver, 1991], but no geometrical bounds. The regional geological history of the Philippines and Indonesia was used as an indicator of where and when extension or shortening had taken place. Rangin et al. [1990b] attempted to describe this complex deformation with simple kinematics, in which most microplates rotate about a pole located in the Andaman Sea [Le Pichon, 1988], deduced from the magnetic anomaly pattern [Briais, 1989].

The southern margin of the South China Sea moves 


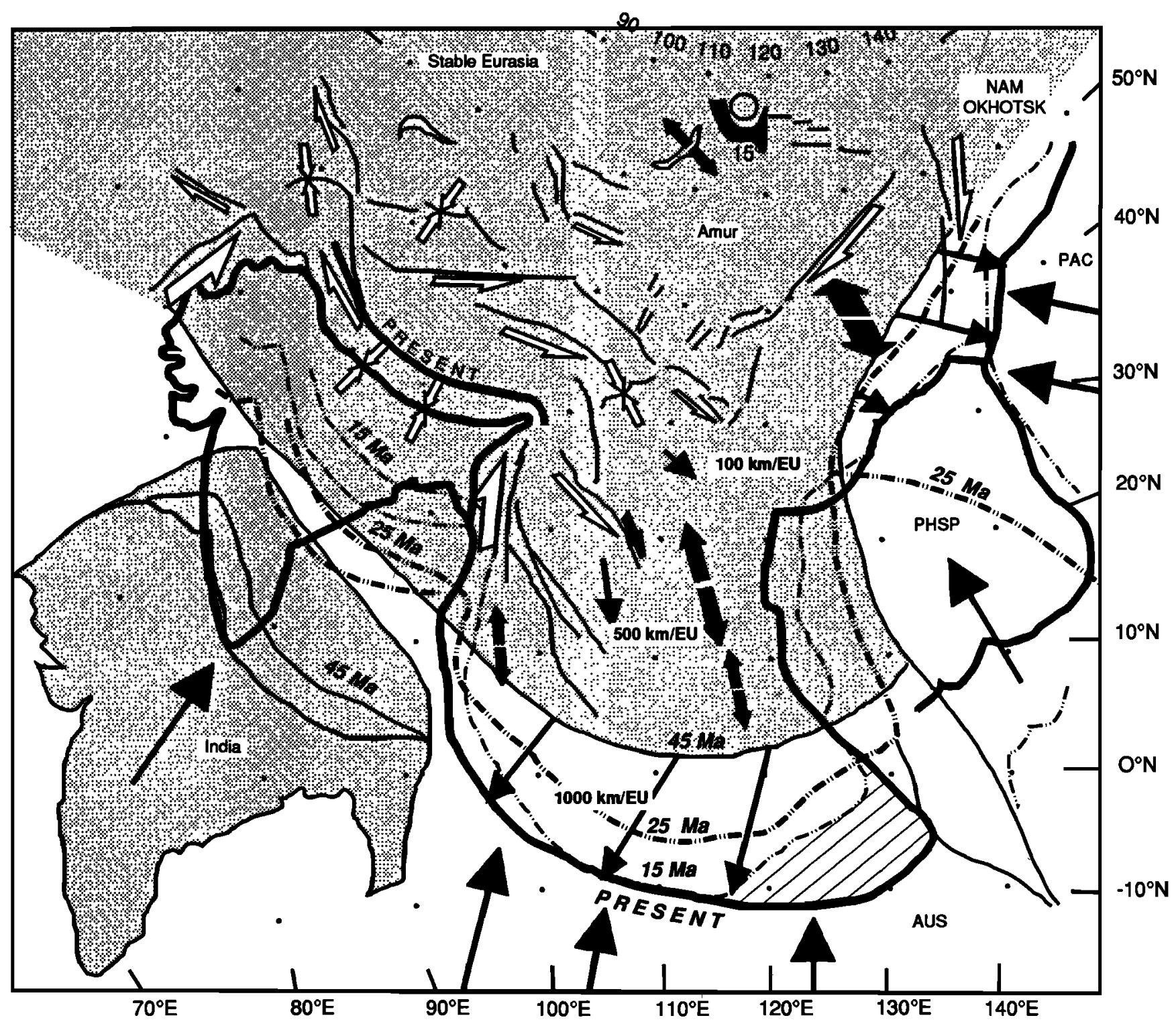

Figure 14. Finite deformation of the eastern and southeastern border of Asia using the reconstructions described in the paper and crude quantification of the displacements.

together with Indochina in the reconstructions, following Tapponnier et al. [1982], who linked the South China Sea opening to extrusion, although we take into account the actual geometry of opening. The displacement of the PHSP is based on (1) paleomagnetic data which give the latitudinal drift and (2) the deformation history of the Philippine archipelago [Jolivet et al., 1989 and references therein]. More precise reconstructions using paleomagnetic data by Haston and Fuller [1991] and Hall et al. [1993] give a similar clockwise rotation and fast northward drift between 25 and $10 \mathrm{Ma}$.

Two periods may be distinguished: first, when most of basins opened (reconstruction at $25 \mathrm{Ma}$ ) and, second, when most began to close while the whole deformed domain began to shorten. The change from the first to the second took place at approximately the time when the first collision of Australia with Indonesia occurred. In the first period, the South China Sea opened close to the eastern termination of the Red River fault. Opening stopped about $15 \mathrm{Ma}$. The Manila trench was formed in the early Miocene [Cardwell et al., 1980] and the South China Sea progressively subducted below the northern Philippine arc. The Sulu Sea began to underthrust the Sulu arc shortly after it opened, and the Celebes Sea was consumed beneath the northern arm of Sulawesi from $15 \mathrm{Ma}$. Sinistral transpressional motion has been active along the Philippine archipelago from at least $20 \mathrm{Ma}$ to the Present, and the present-day Philippine trench was formed some 5 $\mathrm{Ma}$ ago. Most of the sinistral displacement was accommodated along the Philippine fault [Cardwell et al., 1980; Karig et al., 1986; Barrier et al., 1991]. Collision of blocks belonging to the Australian realm started between 20 and $15 \mathrm{Ma}$, which is about the time when the basins started to close.

Reconstructions of Indonesia and Japan were made with a fixed "Eurasia" (North China) adding the relative 
motion of north China with respect to stable Eurasia to obtain the desired reconstructions. Total displacement along the Tien Shan-Baikal-Stanovoy shear zone is known only approximately but is probably fairly small.

There is an acute compatibility problem at the junction between the N-S trending dextral system and the E-W trending left-lateral system south of the North China grabens. The dextral system reactivates the Cretaceous Tanlu fault [Xu et al., 1987; Chen and Nabelek, 1988], but the active domain does not seem to extend south of the Qin Ling ranges, and the Qin Ling fault is not seen east of the Tanlu fault. As argued by Dewey et al. [1989] and Xu et al. [1987], the Tanlu fault is not offset by the E-W trending left-lateral strike-slip system, though its strike changes slightly south of the Qin Ling, preventing any large eastward escape of South China with respect to North China. As shown by Mattauer et al. [1985] and Okay and Sengör [1992], the Tanlu fault does not extend south of the Dabie Shan, which is the Mesozoic thrust front of the Qin Ling range. But the left-lateral activity recongnized by Peltzer et al. [1985] is restricted to the northern part of the Qin Ling and it does not offset the Tanlu fault. This fits the palaeostress field data obtained by Bellier et al. [1988], who suggested that left-lateral motion occurred only in the Plio-Quaternary. In the Miocene the displacement north of the Qin Ling (Wei He graben) was dextral transtension.

Such a junction between two large strike-slip systems that do not offset one another implies some block rotation. Using a comparison with Davy and Cobbold's [1988] experiments, Jolivet et al. [1990] suggested that the eastern part of North China and Japan can be described as a set of dominos rotating counterclockwise in a major leftlateral shear zone, the displacement between the dominos being taken up by dextral motion along the $\mathrm{N}-\mathrm{S}$ dextral strike-slip faults, and a component of extension being expected, as observed in the Japan Sea.

Large-scale deformation is taken up through a leftlateral shear zone which encompasses the region from the Qin Ling to the Stanovoy and accommodated by counterclockwise rotation of dominos and dextral motion. As in the reconstructions, we use a counterclockwise rotation of $15^{\circ}$ since $25 \mathrm{Ma}$ about a pole located to the northeast of Lake Baikal, from Savostin et al. [1983] to fit the extensional tectonics of Lake Baikal and the partly compressional field in the Stanovoy range. This adds an overall eastward displacement of the Korean peninsula and Japan region during the dextral shear and Japan Sea opening. The total displacement along the Altyn-Tagh fault is not known with precision; we assumed a value of $200 \mathrm{~km}$ left-lateral offset in our reconstructions. This strike-slip motion is transfered into crustal thickening in the Nan Shan range, which is in turn partly transfered into left-lateral strike-slip displacement along the Qin Ling fault. Which proportion of the left-lateral motion along the Altyn Tagh fault is transferred into the Qin Ling fault is a matter of debate [Dewey et al., 1989]. Certainly not all displacement can be found to the east, as a part of the eastward displacement of Tibet is taken up along the Longmen Shan thrust zone. A study of recent deformation in the Wei He graben (immediately north of the Qin Ling) also suggests that left-lateral slip is smaller there than more to the west [Bellier et al., 1988]. We considered, in the reconstructions of Indonesia, that some $200 \mathrm{~km}$ is a reasonable number for the total eastward expulsion of South China with respect to Eurasia.

We can then use these three sets of reconstructions to reconstruct the geometry of the eastern and southeastern margins of Asia from $45 \mathrm{Ma}$ to the Present. Four stages have been plotted together in Figure 14 to show the progressive displacement of the borders of Asia in a fixed geographic frame. Stable Eurasia refers to the portion of Asia west and north of the Pamir-Tien Shan-Baikal shear zone [Cobbold and Davy, 1988], which bounds the deformed domain. Given the assumptions described above for the various reconstructions, Figure 14 shows the finite deformation of Asia with respect to a fixed Eurasia from $45 \mathrm{Ma}$ to the present. The displacement of India was taken from Besse and Courtillot [1988], who used both the magnetic lineation data set of the Indian Ocean, as did Patriat and Achache [1984], and the apparent polar wander path of Eurasia [Besse and Courtillot, 1991] to compute the motion of India with respect to Eurasia. For Recent time, motion around the pole of De Mets et al. [1990] was chosen, which takes into account the active shortening in the eastern Indian Ocean. Inception of shortening was chosen at $7 \mathrm{Ma}$, after Leg 116 Shipboard Scientific Party [1987], similar to Le Pichon et al. [1992]. Figure 14 shows crude estimates of the total displacements of the margins of Asia, $400 \mathrm{~km}$ southeastward in the northeast, and $1000 \mathrm{~km}$ southward in the southeast. A shortening of several hundreds of kilometers is seen along the Philippine archipelago concommitantly with the left-lateral motion.

These reconstructions, though unprecise, show a drastic change in the kinematic boundary conditions from the early Miocene to the Present, from basically free subduction all around eastern and southeastern Asia to locked subduction or collision at present. This change led to the closing of most marginal basins formed during the early stage. Based on different kinematic hypotheses or assumptions on the relation between large-scale strike-slip faults and marginal basins opening, one could produce different reconstructions, but all would show the same basic first-order observations: (1) distributed extension and localized spreading occurred in southeast Asia during the Paleocene and early Miocene, (2) back arc extension and spreading was associated with large-scale dextral shear zones in NE Asia between two major left-lateral shear zones, (3) marginal basins closed during the progressive northward motion of the PHSP along the eastern margin of Asia and settling of the T-T-T triple junction in its present position in the middle Miocene and as first effects of the collision of Australia around $20 \mathrm{Ma}$.

Note that we have chosen to link the opening of the South China Sea to left-lateral motion along the Red River fault, as did Tapponnier et al. [1982; 1986], in our reconstructions. This model is not accepted by all authors [Taylor and Hayes, 1983] (also, C. Rangin et al., Cenozoic tectonics of central and South Vietnam: Evidence for superposed tectonic regimes, submitted to Tectonophysics, 1993; hereinafter referred to as Rangin et al., submitted manuscript, 1993) and some prefer to disconnect the opening from extrusion of Indochina. This hypothesis would lead to a slightly different reconstruction in this region, with a much smaller 
extrusion of Indochina, but it would not affect the total displacement of the southern margin of the South China Sea with respect to South China, which is constrained by magnetic anomalies and is thus independent of any a priori model. It would necessitate a large-scale dextral motion along the eastern margin of Vietnam, as postulated by Taylor and Hayes [1983] and recently described from field observations by Rangin et al. (submitted manuscript, 1993) and Huchon et al. [1994].

This dramatic change in kinematic boundary conditions questions the relevance of present-day strain rate measurements in Asia to the finite deformation mechanism. Most discussions and models are concerned with large displacements of several hundreds of kilometers and opening of large rifts and oceanic basins, and therefore deal with finite deformation. If the boundary conditions have changed significantly enough to affect the deformation regime of Asia as a whole, as suggested by the $20 \mathrm{Ma}$ revolution, then the strain rate measurement must be used only to discuss the instantaneous deformation of Asia. The reconstructions suggest that the length of the so-called free boundary of Asia, where extension is active, was reduced progressively through time by the northward drift of the PHSP and the progressive collision of Australia. This leaves only small portions of the Eurasian margin where back arc opening takes place, while it is still active along the eastern margin of the PHSP. If extrusion has occurred, it must be more difficult now than it was in the early Miocene, when the whole eastern and southeastern boundary was subjected to extension; therefore the present-day rates of strike-slip motion along the major faults cannot be extrapolated easily to the past. This is obvious when considering the Red River fault, which no longer acts as a left-lateral guide for extrusion, but was changed to a dextral fault around $15 \mathrm{Ma}$.

\section{Analog Small-Scale Modeling}

Looking for a model which would integrate the deformation of Asia and the deformation of its margins behind subduction zones, Jolivet et al. [1990] used the analog models of Davy and Cobbold [1988] and Cobbold and Davy [1988]. Those models used a "lithosphere" made of silicone putty (lower ductile crust) and dry sand (upper brittle crust) floating on glycose syrup (asthenosphere). They also had simple kinematic boundary conditions, indentation by a rigid indenter, and a stress-free boundary, as in most models considered so far. Most of the deformation was localized in front of the indenter in the form of folding and buckling of the lithosphere, as well as along a wide sinistral N-E trending shear zone which connects the northwest corner of the indenter (Pamir region) to the eastern boundary. Along this shear zone, large-scale dominos rotate counterclockwise between N-S trending transtensional dextral shear zones, which Jolivet et al. [1990] compared to the Sakhalin-Hokkaido-Japan Sea shear zone. Extrusion is not localized along discrete left-lateral shear zones as in Tapponnier et al. [1982], but distributed. In order to investigate the effect of extensional boundary conditions along the eastern and southeastern margins, we (Fournier et al., unpublished manuscript, 1994) performed new experiments with a similar experimental device except for a thinner lithosphere and a larger size experiment. In order to create extension the rheology was chosen so that the "lithosphere" tends to collapse under its own weight. In the absence of indentation the eastern and southeastern boundaries tend to move outward and grabens form perpendicular to gravitational spreading. With such boudary conditions, we applied an indentation at various velocities. Figure 15 shows one of the experiments. The basic features are the following: (1) extrusion is very diffuse and the extruded block is internally severely deformed as in the numerical modeling of Houseman and England [1993], (2) the transtensional dextral strike-slip shear zones are more precisely defined than in the experiments of Davy and Cobbold [1988] and more numerous, and (3) distributed extension is important in the southeastern corner of the model and orientated N-S. These first-order results are similar to the observations we made above on the real object in a first approach.The details seen in this experiment due to its large size and thin lithosphere reveal second-order dominos along the N-S dextral shear zones which rotate clockwise with respect to their surrounding (larger scale dominos which rotate counterclockwise with respect to stable Eurasia). It also reveals dextral pull-apart geometries next to the northeastern boundary. This geometry is similar to that of the Japan Sea. We find here a confirmation of the idea developed by Jolivet et al. [1990] with an emphasis on the role played by extensional boundary conditions.

\section{Discussion}

Several observations can be drawn from this synthesis, some of which are readily discernible from a simple tectonic map of Asia. (1) The displacement of the outer board of Asia with respect to stable Eurasia is apparently larger than the displacement of blocks inside the continent $(1000 \mathrm{~km}$ of southward motion of the Sunda trench versus $500 \mathrm{~km}$ of left-lateral offset along the Red River fault, and this would be even more so without extrusion), (2) the extensional component of the deformation increases toward the back arc regions of the Japan and Sunda trenches, and (3) strike-slip faults (Japan) far from the indenter have accommodated large displacements, as large as those along closer strike-slip faults (Red River, Altyn Tagh).

These observations suggest that the trench roll-back component of subduction played an important role in the deformation of the upper plate. At variance to the assumption made by Tapponnier et al. [1982], Tapponnier et al. [1986], or Peltzer and Tapponnier [1988] for the South China Sea, we believe that the marginal basins of Southeast Asia did not open as "mismatch basins" whose opening is forced along strike-slip shear zones as a result of extrusion, subduction acting only as a passive boundary, but that they opened as the result of active extension in the back arc region, and that their geometry is then controlled by large strike-slip faults.

The Japan Sea and other marginal basins opened in a kinematic and dynamic context which is no longer active today except along the eastern margin of the PHSP. To understand the mechanism of opening of those basins, one must consider the kinematic context active in the early 


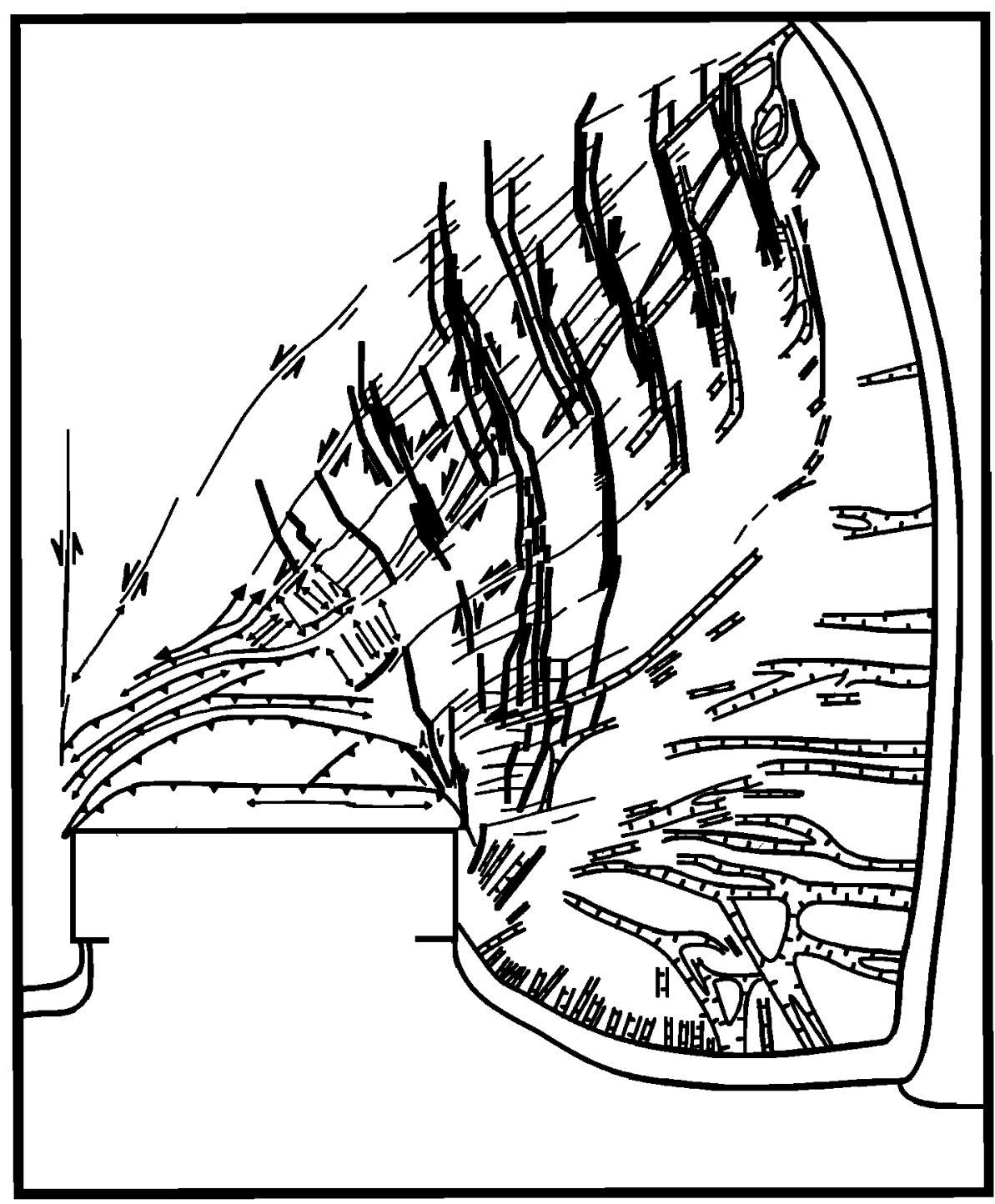

Figure 15. Line drawing of an analog experiment of continental collision (M. Fournier et al., unpublished manuscript, 1994). The strain pattern is shown by faults observed in the sand layer. Fold axes are shown by double arrows. Thrust faults are shown by thin lines with triangles on the upthrust side, normal faults by thin lines with bars on the downthrown side. Dextral strike-slip faults are shown by thick lines, and sinistral ones by thin lines. The box in the lower left corner is the rigid indenter. The total length of the experiment is $1.20 \mathrm{~m}$ (from M. Fournier et al., unpublished manuscript, 1994).

Miocene, and reconstructions with their inherent large errors are an essential step. A comparison of the $25 \mathrm{Ma}$ reconstruction and the present-day situation shows how the evolution of the boundary condition along the subduction zones and the deformation of Asia may be related. At $25 \mathrm{Ma}$, trench roll-back was probably active along all of the Sunda, Japan and Kuril trenches. The situation was different along the proto-Philippine fault, where left-lateral strike-slip was active and the western tip of the Bonin arc was moving along the eastern margin of Eurasia. Stress conditions were most likely less extensional along this boundary. During this period, N-S extension and spreading were active behind the Sunda trench in the South China Sea, and the region of Japan was dragged eastward behind the Pacific subduction. At 15 $\mathrm{Ma}$, the Bonin arc had reached central Japan and was no longer impinging the eastern margin of the Philippines and South China, whereas collision of Australia was active in the south. The stress regime had evolved toward a different situation, where the eastern part of the Sunda trench was no longer subjected to trench roll-back and extension but instead to compression. The Ryukyu arc was now facing a free subduction of the oceanic lithosphere of the PHSP, and central Japan experienced the beginning of the Bonin arc collision. This new situation was progressively introduced from 20 to $10 \mathrm{Ma}$. Without the trench roll-back along the Sunda trench, Southeast Asia was no longer dragged southward, and the direction of spreading consequently changed in the South China Sea as discussed above. South China was then dragged toward the east between two more constrained regions, collisions of Australia, Taiwan, and the Bonin arc. It could escape 
between the left-lateral Qin Ling fault and the dextral Red River fault, leading to the present situation. Note that during this complex evolution, back arc spreading was continuously active behind the Bonin arc in the ShikokuParece Vela basin and the Mariana trough.

The Japan Sea is thus under the influence of two largescale phenomena: "classical" back arc spreading provided the extensional component, and internal deformation of Asia due to the collision of India provided the dextral strike-slip component. We have no original mechanism to originate extension other than the one usually considered after Uyeda and Kanamori [1979]. We only emphasize here that the Japan Sea is part of the western Pacific back arc basins whose opening is due to subduction, whatever the exact mechanism, which is still controversial, as well as the result of the internal deformation of Asia during its collision with India. Without collision, the Japan Sea would have opened as a symmetrical back arc basin similar to the Shikoku basin. If there is no agreement on the possible link between the opening of the South China Sea and the left-lateral motion along the Red River fault because the connection between the two systems is obscured, we can show a connection between the dextral motion along the Sakhalin-Hokkaido shear zone and the Japan Sea opening: the pull-apart geometry is there inescapable.

Acknowledgments. This synthesis is the result of many years of research in Japan in the field as well as on board oceanographic vessels. Laurent Jolivet is indebted to many of his colleagues in Japan, among them M. Nakagawa, N. Kito, T. Bamba, S. Miyashita and his family, and G. Kimura. Thanks are due also to J.P. Cadet, J. Charvet, X. le Pichon, P. Huchon, P. Davy, J.P. Brun and C. Rangin. Thanks are due also to V. Rozdestvenskiy, K. Sergeyev, O. Melnikov, R. Kovalenko and H. Gnibidenko for the time they spent with us in the field in Sakhalin. We benefited also from discussions with T. Ohguchi, K. Kaneko, Y.I. Otofuji, R. Tada and A. Yamaji. S. Uyeda and J.F. Dewey have also encouraged this work.

\section{References}

Amano, K., and H. Sato, Neogene tectonics of the central part of the northeast Honshu arc, Mem. Soc. Geol. Jpn., 32, 81-96, 1989.

Barrier, E., P. Huchon, and M. Aurelio, Philippine fault: A key for Philippine kinematics, Geology, 19, 32-35, 1991.

Bellier, O., J.L. Mercier, P. Vergely, C. Long, and C. Ning, Evolution sédimentaire et tectonique du graben bénozoique de la Wei He (province du Shaanxi, Chine du Nord), Bull. Soc. Geol. France, 4, 979-994, 1988.

Besse, J., and V. Courtillot, Paleogeographic maps of the Indian Ocean bordering continents since the Upper Jurassic, $J$. Geophys. Res., 94, 2787-2838, 1988.

Besse, J., and V. Courtillot, Revised and synthetic apparent polar wander path of the African, Eurasian, North American and Indian plates, and time polar wander since $200 \mathrm{Ma}, J$. Geophys. Res., 96, 4029-4050, 1991.

Briais, A., Cinematique d'ouverture de la mer de Chine du Sud (Nanhai), implications pour la tectonique tertiaire de l'Asie, thèse, Paris, 239 pp., Univ. Pierre et Marie Curie, 1989.

Briais, A., P. Patriat, and P. Tapponnier, Updated interpretation of magnetic anomalies and seafloor spreading stages in the South China Sea: Implications for the tertiary tectonics of southeast Asia, J. Geophys. Res., 98, 6299-6328, 1993.

Cadet, J. P., and K. Fujioka, Neogene volcanic ashes and explosive volcanism: Japan trench transect, Initial Rep. Deep Sea Drill. Proj., 1027-1041, 1980.

Cardwell, R.K., B. L. Isacks, and D. E. Karig, The spatial distribution of earthquakes, focal mechanism solutions, and subducted lithosphere in the Philippine and northern Indonesian islands, in The Tectonic and Geologic Evolution of Southeast Asian Seas and Islands, Part 1, Geophys. Monogr. Ser., vol. 23, edited by D.E. Hayes, pp. 1-36, AGU, Washington, D.C., 1980.

Chamot-Rooke, N., V. Renard, and X. Le Pichon, Magnetic anomalies in the Shikoku basin: A new interpretation, Earth Planet. Sci. Lett., 83, 214-223, 1987.

Chapman, M. C., and S. C. Solomon, North American-Eurasian plate boundary in northeast Asia, J. Geophys. Res., 81, 921$930,1976$.

Charvet, J., and $O$. Fabbri, Vue générale sur l'orogénèse Shimanto et l'évolution tertiaire du Japon sud-ouest, Bull. Soc. Geol. France, 3, 1171-1188, 1987.

Charvet, J., K. Grimm, J. Griffin, L. Jolivet and A. Pouclet, Structural features in ODP leg 128 cores: relationship with the tectonic evolution of the Japan Sea, Proc. Ocean Drill. Program Sci. Results, 127-128, part 2, 1175-1193, 1992.

Chen, W.P., and J. Nabelek, Seismogenic strike-slip faulting and the development of the North China basin, Tectonics, 7, 975$989,1988$.

Cobbold, P.R., and P. Davy, Indentation tectonics in nature and experiments, 2, Central Asia, Bull. Geol. Inst. Univ. Uppsala, 14, 143-162, 1988.

Davy, P., and P. R. Cobbold, Indentation tectonics in nature and experiments: Experiments scaled for gravity, Bull. Geol. Inst. Univ. Uppsala, 14, 129-141, 1988.

De Mets, C., A test of present-day plate geometries for northeast Asia and Japan, J. Geophys. Res., 97, 17,627-17,635, 1992.

De Mets, C., R. G. Gordon, D. F. Argus, and S. Stein, Current plate motions, Geophys. J. Int., 101, 425-478, 1990.

de Vries Klein, G., and K. Kobayashi, Geological summary of the north Philippine Sea, based on DSDP leg 58 results, Initial Rep. Deep Sea Drill. Project, 58, 951-962, 1980.

Dewey, J.F., S. Cande, and W. C. Pitman, Tectonic evolution of the India-Eurasia collision zone, Eclogae Geol. Helv., 82, 717-734, 1989.

Fournier, M., L. Jolivet, P. Huchon, K. F. Sergeyev, and L. Oscorbin, Neogene strike-slip faulting in Sakhalin and the Japan Sea opening, J. Geophys. Res., 99, 2701-2725, 1994.

Fujioka, K., Synthesis of Neogene explosive volcanism of the Tohoku arc, deduced from the marine tephra drilled around the Japan trench region, Deep Sea Drill. Project Initial Rep., 87, 703-721, 1986.

Fukao, Y., and M. Furumoto, Mechanisms of large earthquakes along the eastern margin of the Japan Sea, Tectonophysics, 25, 247-266, 1975.

Hall, R., M. Fuller, J.R. Ali, and L. Jolivet, The Philippine Sea plate: Magnetism and reconstructions, AGU Monograph, in press, 1993.

Hamilton, W., Tectonics of the Indonesian region, U.S. Geol. Surv. Prof. Pap., 1078, 345 pp., 1979.

Haston, R.B., and M. Fuller, Paleomagnetic data from the Philippine Sea plate and their tectonic significance, $J$. Geophys. Res., 96, 6073-6098, 1991.

Hayashida, A., Timing of rotational motion of southwest Japan inferred from paleomagnetism of the Setouchi Miocene series, J. Geomagn. Geoelectr., 38, 295-310, 1986.

Hayashida, A., T. Fukui, and M. Torii, Paleomagnetism of the Early Miocene Kani group in southwest Japan and its implication for the opening of the Japan Sea, Geophys. Res. Lett., 18, 1095-1098, 1991.

Honza, E., The Tertiary arc chain in the western Pacific, Tectonophysics, 187, 285-303, 1991.

Houseman, G. and P. England, Crustal thickening versus lateral 
expulsion in the Indian-Asian continental collision, $J$. Geophys. Res., 98, 12233-12249, 1993.

Huchon, P., Géodynamique de la zone de collision d'Izu et du point triple du Japon Central, Thèse de Doctorat, 414 pp., Univ. Pierre et Marie Curie, Paris, 1985.

Huchon, P., X. Le Pichon, and C. Rangin, Indochina peninsula and the collision of India and Eurasia, Geology, 22, 27-30, 1994.

Iijima, A., and R. Tada, Evolution of Tertiary sedimentary basins of Japan in reference to opening of the Japan Sea, J. Fac. Sci. Univ. Tokyo, 22, 121-171, 1990.

Iijima, A., R. Tada, and Y. Watanabe, Development of Neogene sedimentary basins in the northeastern Honshu arc with emphasis on Miocene siliceous deposits. J. Fac. Sci. Tokyo Univ., 21, 417-446, 1988.

Ingle, C.J., Subsidence of the Japan Sea: Stratigraphic evidence from ODP sites and onshore sections, Proc. Ocean Drill. Program Sci. Reesults, 127-128, 1197-1218, 1992.

Ingle, C.J., et al., Proc. Ocean Drill. Program Initial Rep., 128, 5-38, 1990.

Ito, T., M. Utada, and T. Okuyama, Mio-Pliocene calderas in the backbone region in northeast Japan, Mem. Geol. Soc. Jpn., 32, 409-429, 1989.

Jolivet, L., and P. Huchon, Crustal scale strike-slip deformation in Hokkaido, northeast Japan, J. Struct. Geol., 11, 509-522, 1989.

Jolivet, L., and S. Miyashita, The Hidaka shear zone (Hokkaido, Japan): Genesis during a right-lateral strike slip movement, Tectonics, 4, 289-302, 1985.

Jolivet, L., and K. Tamaki, Neogene kinematics in the Japan Sea region and the volcanic activity of the northeast Japan arc, Proc. Ocean Drill. Program Sci. Reesults, 127-128, 13111331, 1992.

Jolivet, L., P. Huchon, and C. Rangin, Tectonic setting of western Pacific marginal basins, Tectonophysics, 160, 23-47, 1989.

Jolivet, L., P. Davy, and P.R. Cobbold, Right-lateral shear along the northwest Pacific margin and the India-Eurasia collision, Tectonics, 9, 1409-1419, 1990.

Jolivet, L., P. Huchon, J.P. Brun, N. Chamot-Rooke, X. Le Pichon, and J.C. Thomas, Arc deformation and marginal basin opening, Japan Sea as a case study, J. Geophys. Res., 96, 4367-4384, 1991.

Jolivet, L., M. Fournier, P. Huchon, V. S. Rozhdestvenskiy, K. F. Sergeyev, and L. S. Oscorbin, Cenozoic intracontinental dextral motion in the Okhotsk-Japan Sea region, Tectonics, 11, 968-977, 1992.

Jun, M. S., Source parameters of shallow intraplate earthquakes in and around the Korean peninsula and their tectonic implication, Acta Univ.Ups., Comprehensive Summaries of Uppsala Diss. Fac. Sci., 285, 16 pp., 1990.

Kanaori, Y., Late Mesozoic-Cenozoic strike-slip and block rotation in the inner belt of southwest Japan. Tectonophysics, 177, 381-399, 1990.

Karig, D.E., Origin and development of marginal basins in the western Pacific, J. Geophys. Res., 76, 2542-2561, 1971.

Karig, D.E., R. N. Anderson, and L. D. Bibee, Characteristics of back arc spreading in the Mariana Trough, J. Geophys. Res., 83, 1213-1226, 1978.

Karig, D.E., D. R. Sarewitz, and G. D. J. Haeck, Role of strikeslip faulting in the evolution of allochtonous terranes in the Philippines, Geology, 14, 852-855, 1986.

Kimura, G. and K. Tamaki, Tectonic framework of the Kuril arc since its initiation, in Formation of Active Ocean Margins, edited by N. Nasu et al., pp. 641-676, Terrapub, Tokyo, 1985.

Kimura, G. and K. Tamaki, Collision, rotation and back arc spreading: The case of the Okhotsk and Japan Seas, Tectonics, 5, 389-401, 1986.

Kimura, M., Back arc rifting in the Okinawa Trough, Mar. Pet. Geol., 2, 222-240, 1985.
Kodama, K., and K. I. Nakayama, Paleomagnetic evidence for post-late Miocene intra-arc rotation of South Kyushu, Japan, Tectonics, 12, 35-47, 1993.

Lallemand, S., and L. Jolivet, Japan Sea: A pull-apart basin, Earth Planet. Sci. Lett., 76, 375-389, 1985.

Lee, C.S., and R. McCabe, The Banda-Celebes-Sulu basin: A trapped piece of Cretaceous-Eocene oceanic crust, Nature, 322, 51-53, 1986.

Leg 116 Shipboard Scientific Party, Collision in the Indian ocean, Nature, 330, 519-521, 1987.

Le Pichon, X., Résumé des cours et travaux, Annuaire du Collège de France 1987-1988, pp. 135-144, College de France, Paris, 1988.

Le Pichon, X., M. Fournier, and L. Jolivet, Kinematics, topography and extrusion in the India-Eurasia collision, Tectonics, 11, 1085-1098, 1992.

Letouzey, J., and M. Kimura, Okinawa trough genesis: Structure and evolution of a back arc basin developed in a continent. Mar. Pet. Geol., 2, 111-130, 1985.

Matsuda, T., Collision of the Izu-Bonin arc with central Honshu: Cenozoic tectonics of the Fossa Magna, Japan. J. Phys. Earth, 26, suppl., 409-421, 1978.

Mattauer, M., P. Matte, J. Malavielle, P. Tapponnier, H. Maluski, Z.Q. Xu, Y.L. Lu, and Y.Q. Tang, Tectonics of the Qinling belt: Buildup and evolution of eastern Asia, Nature, 317, 496-500, 1985.

Miyasaka, S., K. Hoyanagi, Y. Watanabe, and M. Matsui, Late Cenozoic mountain building in central Hokkaido, deduced from the composition of conglomerate, in Geology and Tectonics of Hokkaido, pp. 285-294, Monograph Association and Geological Collaboration, 1986.

Mrozowski, C.L., and D. E. Hayes, The evolution of the Parece Vela basin, eastern Philippine Sea, Earth Planet. Sci. Lett., 46, 49-67, 1979.

Nakamura, K., Possible nascent trench along the eastern Japan Sea as the convergent boundary between Eurasia and North American plates (in Japanese), Bull. Earthquake Res. Inst., $58,721-732,1983$.

Nakamura, K., and S. Uyeda, Stress gradient in back arc regions and plate subduction, J. Geophys. Res., 85, 6419-6428, 1980.

Niitsuma, N., and F. Akiba, Neogene tectonic evolution and plate subduction in the Japanese island arc, Formation of Active Ocean Margins, in N. Nasu, S. Uyeda, and H. Kagami, pp. 75-108, edited by Terra publishers, Tokyo, 1985.

Ohguchi, T., T. Yoshida, and K. Okami, Historical change of the Neogene and Quaternary volcanic field in the northeast Honshu arc, Japan, Mem. Geol. Soc. Jpn., 32, 431-455, 1989.

Okada, A., Quaternary faulting along the median tectonic line of southwest Japan, Mem.Geol. Soc. Jpn, 18, 79-108, 1980.

Okay, A.I., and A. M. C. Sengör, Evidence for intracontinental thrust-related exhumation of the ultra-high pressure rocks in China, Geology, 20, 411-414, 1992.

Otofuji, Y., and T. Matsuda, Paleomagnetic evidence for the clockwise rotation of southwest Japan, Earth. Planet. Sci. Lett., 62, 349-359, 1983.

Otofuji, Y., and T. Matsuda, Timing of rotational motion of southwest Japan inferred from paleomagnetism, Earth Planet. Sci. Lett., 70, 373-382, 1984.

Otofuji ,Y. , and T. Matsuda, Amount of clockwise rotation of Southwest Japan-Fan shape opening of the southwestern part of the Japan Sea, Earth Planet. Sci. Lett., 85, 289-301, 1987.

Otofuji, Y., T. Matsuda T., and S. Nohda, Paleomagnetic evidences for the Miocene counterclockwise rotation of northeast Japan-Rifting process of the Japan arc, Earth Planet. Sci. Lett., 75, 265-277, 1985.

Otofuji, Y., T. Itaya, and T. Matsuda, Rapid rotation of southwest Japan-Paleomagnetism and K-Ar ages of Miocene volcanic rocks of southwest Japan, Geophys. J. Int., 105, 397-405, 1991. 
Otsuki, K., Reconstruction of Neogene tectonic stress field of northeast Honshu arc from metalliferous veins, Mem. Soc. Geol. Jpn., 32, 281-304, 1989.

Park, C.H., K. Tamaki, and K. Kobayashi, Age-depth correlation of the Philippine Sea back arc basins and other marginal basins in the world, Tectonophysics, 181, 351-371, 1990.

Patriat, P., and J. Achache, India-Asia collision chronology has implications for crustal shortening and driving mechanisms of plates, Nature, 311, 615-621, 1984.

Peltzer, G., and P. Tapponnier, Formation and evolution of strikeslip faults, rifts and basins during the India-Asia collision: An experimental approach. J. Geophys. Res., 93, 15085-15118, 1988.

Peltzer, G., P. Tapponnier, Z.T. Zheng, and Z.Q. Xu, Neogene and Quaternary faulting in and along the Qin Ling Shan, Nature, 317, 500-505, 1985.

Rangin, C., and E. A. Silver, Neogene tectonic evolution of the Celebes-Sulu Sea basins: New insights from leg 124 drilling, Proc. Ocean Drill. Program Sci. Results, 124, 51-64, 1991.

Rangin, C., et al., Proceedings of the Ocean Drilling Program Initial reports, vol. 124, Ocean Drilling Program, College Station, Texas, 1990a.

Rangin, C., et al., A simple model for the tectonic evolution of southeast Asia and Indonesia region for the past $43 \mathrm{Ma}, B$ bull. Soc. Geol. France, 6, 889-906, 1990b.

Ranken, B., R. K. Cardwell, and D. E. Karig, Kinematics of the Philippine Sea plate, Tectonics, 3, 555-575, 1984.

Rozhdestvenskiy, V.S., The role of wrench faults in the structure of Sakhalin, Geotectonics, 16, 323-332, 1982.

$\mathrm{Ru}, \mathrm{K}$., and J. P. Pigott, Episodic rifting and subsidence in the South China Sea, Am. Assoc. Petrol. Geol. Bull., 79, 1136$1155,1986$.

Savostin, L., L. Zonenshain, and B. Baranov, Geology and plate tectonics of the Sea of Okhotsk, in Geodynamics of the Western Pacific-Indonesian region, edited by W. C. T. Hilde and S. Uyeda, Geodynamic Ser., vol. 11, 343-354, AGU, Washington, D. C., 1983.

Seno, T., The instantaneous rotation vector of the Philippine Sea plate relative to the Eurasian plate, Tectonophysics, 42, 209226, 1977.

Seno, T., Age of subducting lithosphere and back arc basin formation in the western Pacific since the middle Tertiary, in Formation of Active Ocean Margins, edited by N. Nasu et al., pp. 469-481, Terrapub, Tokyo, 1985.

Shemenda, A. I., Subduction of the lithosphere and back arc dynamics: Insights from physical modeling, J. Geophys. Res., 98, 16,167-16,185, 1993.

Shih, T.C., Marine magnetic anomalies from the western Philippine Sea: Implications for the evolution of marginal basins, in The Tectonic and Geologic Evolution of Southeast Asian Seas and Islands, part 1, Geophys. Monogr. Ser., vol. 23, edited by D.E. Hayes, pp. 49-75, AGU, Washingon, D. C., 1980.

Sibuet, J.C., J. Letouzey, F. Barbier, J. Charvet, J.P. Foucher, T.W.C. Hilde, M. Kimura, C. Lin-Yun, B. Marsset, C. Muller, and J.F. Stephan, Back arc extension in the Okinawa trough, J. Geophys. Res., 92, 14,041-14,063, 1987.

Sillitoe, R. H., Metallogeny of an Andean type continental margin in South Korea: Implications for opening of the Japan Sea, Island Arcs, Deep Sea Trenches and Back Arc Basins, Maurice Ewing Ser., vol. 1, edited by M. Talwani and W. C. Pitman, pp. 303-310, AGU, Washington, D. C., 1977.

Silver, E.A., and C. Rangin, Leg 124 tectonic synthesis, Proc. Ocean Drill. Program Sci. Results, 124, 3-10, 1991a.

Silver, E.A., and C. Rangin, Development of the Celebes Sea basin in the context of western Pacific marginal basin history, Proc. Ocean Drill. Program Sci. Results, 39-50, 1991b.

Stern, R.J., N. C. Smoot, and M. Rubin, Unzipping of the volcano arc, Japan, Tectonophysics, 102, 153-174, 1984.
Stock, J., and P. Molnar, Uncertainties in the relative position of the Australia, Antarctica, Lord Howe, and Pacific plates since the late Cretaceous, J. Geophys. Res., 87, 4697-4714, 1982.

Sugi, N., K. Chinzei, and S. Uyeda, Vertical crustal movements of northeast Japan since middle Miocene, in Geodynamics of the Western Pacific-Indonesian regions, Geodyn. Ser., vol. 11, edited by W.C.T. Hilde and S. Uyeda, pp. 317-329, AGU, Washington, D. C., 1983.

Sugimura, A., T. Matsuda, K. Chinzei, and K. Nakamura, Quantitative distribution of late Cenozoic volcanic material in Japan, Bull. Volcanol., 26, 125-140, 1963.

Suzuki, K., On the late Cenozoic history in the southern part of northeast Honshu in Japan, Mem. Geol. Soc. Jpn., 32, 97-112, 1989.

Taira, A., H. Tokuyama, and W. Soh, Accretion tectonics and evolution of Japan, in The Evolution of the Pacific Ocean Margin, edited by Z.Ben Avraham, pp. 100-123, Oxford University Press, New York, 1989.

Tamaki, K., Age estimation of the Japan Sea on the basis of stratigraphy, basement depth and heat flow data, J. Geomagn. Geoelectr., 38, 427-446, 1986.

Tamaki, K., Geological structure of the Japan Sea and its tectonic implications, Bull. Geol. Surv. Jpn., 39, 269-365, 1988.

Tamaki, K., and E. Honza, Incipient subduction and obduction along the eastern margin of the Japan Sea, Tectonophysics, $119,381-406,1984$.

Tamaki, K., and E. Honza, Global tectonics and formation of marginal basins: Role of the western Pacific, Episodes, 14, 224-230, 1991.

Tamaki, K., and K. Kobayashi, Geomagnetic anomaly lineation in the Japan Sea (in Japanese), Marine Sci. Monthly, 20, 705$710,1988$.

Tamaki, K., K. Suyehiro, J. Allan, J. C. Ingle, and K. Pisciotto, Tectonic synthesis and implications of Japan Sea ODP drilling, Proc. Ocean Drill. Program Sci. Results, 127-128, 1333-1350, 1992.

Tapponnier, P., G. Peltzer, Y. Le Dain, R. Armijo, and P. Cobbold, Propagating extrusion tectonics in Asia: New insights from simple experiments with plasticine, Geology, 10, 611-616, 1982.

Tapponnier, P., G. Peltzer, and R. Armijo, On the mechanics of the collision between India and Asia, Collision Tectonics, edited by M. P. Coward and A. C. Ries, Geol. Soc. Spec. Publ., 19, 115-157, 1986.

Tapponnier, P., R. Lacassin, P.H. Leloup, U. Schärer, Z. Dalai, W. Haiwei, L. Xiaohan, J. Shaocheng, Z. Lianshang, and Z. Jiayou, The Ailao Shan/Red River metamorphic belt: Tertiary left-lateral shear between Indochina and South China, Nature, 343, 431-437, 1990.

Tatsumi, Y., Y. I. Otofuji, T. Matsuda, and S. Nohda, Opening of the sea of Japan back arc basin by asthenospheric injection, Tectonophysics, 166, 317-329, 1989.

Taylor, B., Rifting and the volcanic-tectonic evolution of the IzuBonin-Mariana arc, Proc. Ocean Drill. Program Sci. Res., 126, 627-651, 1992.

Taylor, B. and D. E. Hayes, The tectonic evolution of the south China basin, in: Hayes D. E., Ed., The tectonic and geologic evolution of southeast Asian seas and islands, Geophys. Monogr., AGU, Washington, 27, 89-104, 1980.

Taylor, B., and D. E. Hayes, Origin and history of the South China Sea basin, in The Tectonic and Geologic Evolution of Southeast Asian Seas and Islands, part 2, edited by D.E. Hayes, Geoph. Monogr., vol. 27, 23-56, AGU, Washington, D. C., 1983.

Taylor, B. and G. D. Karner, On the evolution of marginal basins, Rev. Geophys., 21, 1727-1741, 1983.

Taylor, B., et al., Proceedings of the Ocean Drilling Program Initial reports, vol. 126, Ocean Drilling Program, College Station, Texas, 1990. 
Tokuyama, H., M. Suyemasu, K. Tamaki, E. Nishiyama, S. Kuramoto, K. Suyehiro, H. Kinoshita, and A. Taira, Report on DELP cruises in the Japan Sea, part III, Seismic reflection studies in the Yamato basin and the Yamato Rise area, Bull. Earthquake Res. Inst., Univ. Tokyo, 62, 367-390, 1987.

Tosha, T., and Y. Hamano, Paleomagnetism of Tertiary rocks from the Oga peninsula and the rotation of northeast Japan, Tectonics, 7, 653-662, 1988.

Tsuchiya, N., Submarine basalt volcanism of Miocene Aosawa formation in the Akita-Yamagata oil filled basin, back-arc region of northeast Japan, Mem. Geol. Soc. Jpn., 32, 399-408, 1989.

Usuta, M., Geotectonic history of the southern part of Akita prefecture, northeast Japan, Mem. Geol. Soc. Jpn., 32, 57-80, 1989.

Uyeda, S., Facts, ideas and open problems on trench-arc-back arc systems, in The origin of arcs, eedited by F.C. Wezel, Pp. 435-460, Elsevier, New York, 1986.

Uyeda, S., and H. Kanamori, Back arc opening and the mode of subduction, J. Geophys. Res., 84, 1049-1061, 1979.

Uyeda, S. and R. McCabe, A possible mechanism of episodic spreading of the Philippine Sea, in Accretion Tectonics in the Circum Pacific Region, edited by M. Hashimoto and S. Uyeda, pp. 291-306, Terrapub, Tokyo, 1983.

Viallon, C., P. Huchon, and E. Barrier, Opening of the Okinawa basin and collision in Taiwan: A retreating trench model with iateral anchoring, Earth Planet. Sci. Lett., 80, 145-155, 1986.
Von Huene, R., and S. Lallemand, Tectonic erosion of the Japan and Peru convergent margins, Geol. Soc. Am. Bull., 102, 704$720,1990$.

Wageman, J.M., T.W.C. Hilde, and K. O. Emery, Structural framework of the East China Sea and Yellow Sea, Am. Assoc. Pet. Geol. Bull., 54, 1611-1643, 1970.

Xu, J., G. Zhu, W. X. Tong, K. R. Cui, and Q. Liu, Formation and evolution of the Tancheng-Lujiang wrench fault sytem to the northwest of the Pacific Ocean, Tectonophysics, 134, 273$310,1987$.

Yahata, M., Cenozoic system and its geotectonic features of the northern part of southwest Hokkaido, Japan, Mem. Geol. Soc. Jpn., 32, 7-28, 1989.

Yamaji, M., Geology of Atsumi area and early Miocene rifting in the Uetsu district, northeast Japan, Mem. Geol. Soc. Jpn., 32, 305-320, 1989.

M. Fournier and L. Jolivet, Laboratoire de Geologie, Département Terre-Atmosphère-Ocean, Ecole Normale Supérieure, 24 rue Lhomond, 75231, Paris cedex 05, France. K. Tamaki, Ocean Research Institute, University of Tokyo, 1-15-1 Minami Dai, Nakano Ku, Tokyo 164, Japan.

(Received May 7, 1993; revised October 28, 1993; accepled December 6, 1993.) 